\title{
Aerosol data assimilation in the chemical transport model MOCAGE during the TRAQA/ChArMEx campaign: aerosol optical depth
}

\author{
Bojan Sič ${ }^{1,2}$, Laaziz El Amraoui ${ }^{1}$, Andrea Piacentini ${ }^{2}$, Virginie Marécal ${ }^{1}$, Emanuele Emili $^{2}$, Daniel Cariolle $^{2}$, \\ Michael Prather ${ }^{3}$, and Jean-Luc Attié ${ }^{1,4}$ \\ ${ }^{1}$ CNRM-GAME, Météo-France - CNRS, UMR3589, Toulouse, France \\ ${ }^{2}$ CECI, CERFACS - CNRS, UMR5318, Toulouse, France \\ ${ }^{3}$ Department of Earth System Science, University of California, Irvine, USA \\ ${ }^{4}$ Laboratoire d'Aérologie, University of Toulouse - CNRS, UMR5560, Toulouse, France
}

Correspondence to: Bojan Sič (bojanovmejl@gmail.com)

Received: 26 February 2016 - Published in Atmos. Meas. Tech. Discuss.: 7 April 2016

Revised: 20 September 2016 - Accepted: 22 September 2016 - Published: 22 November 2016

\begin{abstract}
In this study, we describe the development of the aerosol optical depth (AOD) assimilation module in the chemistry transport model (CTM) MOCAGE (Modèle de Chimie Atmosphérique à Grande Echelle). Our goal is to assimilate the spatially averaged 2-D column AOD data from the National Aeronautics and Space Administration (NASA) Moderate-resolution Imaging Spectroradiometer (MODIS) instrument, and to estimate improvements in a 3-D CTM assimilation run compared to a direct model run. Our assimilation system uses 3-D-FGAT (first guess at appropriate time) as an assimilation method and the total 3-D aerosol concentration as a control variable. In order to have an extensive validation dataset, we carried out our experiment in the northern summer of 2012 when the pre-ChArMEx (CHemistry and AeRosol MEditerranean EXperiment) field campaign TRAQA (TRAnsport à longue distance et Qualité de l'Air dans le bassin méditerranéen) took place in the western Mediterranean basin. The assimilated model run is evaluated independently against a range of aerosol properties (2$\mathrm{D}$ and 3-D) measured by in situ instruments (the TRAQA size-resolved balloon and aircraft measurements), the satellite Spinning Enhanced Visible and InfraRed Imager (SEVIRI) instrument and ground-based instruments from the Aerosol Robotic Network (AERONET) network. The evaluation demonstrates that the AOD assimilation greatly improves aerosol representation in the model. For example, the comparison of the direct and the assimilated model run with
\end{abstract}

AERONET data shows that the assimilation increased the correlation (from 0.74 to 0.88 ), and reduced the bias (from 0.050 to 0.006 ) and the root mean square error in the AOD (from 0.12 to 0.07 ). When compared to the 3 -D concentration data obtained by the in situ aircraft and balloon measurements, the assimilation consistently improves the model output. The best results as expected occur when the shape of the vertical profile is correctly simulated by the direct model. We also examine how the assimilation can influence the modelled aerosol vertical distribution. The results show that a 2 D continuous AOD assimilation can improve the 3-D vertical profile, as a result of differential horizontal transport of aerosols in the model.

\section{Introduction}

In recent years, the role of aerosols in the climate system has been better determined (Boucher et al., 2013). As a consequence, efforts to accurately represent aerosols in models also increased (for example Kanakidou et al., 2005; Textor et al., 2006; Fuzzi et al., 2006; Vignati et al., 2010; Lee et al., 2011; Boucher et al., 2013; Sič et al., 2015). The development of aerosol modelling enables us to better understand how aerosols affect atmospheric chemistry, air quality, climate, aviation, visibility, radiative budget and clouds. Still, the complexity of the processes governing aerosol physics 
and chemistry has led to a large diversity of parametrizations which with other uncertainties (e.g. dynamics, emissions, initial conditions) produce large differences in the aerosol model results (Mahowald et al., 2003; Kinne et al., 2006; Textor et al., 2006; Shindell et al., 2013).

At the same time, the number and quality of aerosol observations has also increased through advances in sensing technology and techniques. The last decade of aerosol research has brought on more accurate measurements of more specific aerosol characteristics observed from local to global scales and over long periods of time (De Leeuw et al., 2011). In essence, we are in a golden age of aerosol data, but still looking for approaches to merge all the disparate measurements and synthesize that knowledge (Boucher et al., 2013).

Observations are crucial in identifying aerosol properties and processes, which in turn help build more accurate models. Additionally, with data assimilation techniques, we are able to directly integrate observations in models in order to improve modelled fields (Fisher and Lary, 1995; Elbern et al., 1997). Up to now, several research groups made efforts to assimilate aerosols in the models. These efforts are mainly focused on assimilating satellite data, usually aerosol optical depth (AOD), since satellites provide continuous aerosol observations on the global scale and yield a large number of individual observations, which is desirable for assimilation systems. Many studies have used variational data assimilation techniques. For example, a 3-D-VAR system for assimilating AOD data was built by Zhang et al. (2008) in the Naval Research Laboratory's (NRL) Aerosol Analysis and Prediction System (NAAPS), by Niu et al. (2008) in the Chinese Unified Atmospheric Chemistry Environment - Dust (CUACE/Dust) system, and by Liu et al. (2011) in the National Centers For Environmental Prediction's (NCEP) Weather Research and Forecasting-Chemistry/Goddard Chemistry Aerosol Radiation and Transport/Gridpoint Statistical Interpolation (WRFChem/GOCART/GSI) system. Benedetti et al. (2009) described the assimilation of AOD in the European Centre for Medium-Range Weather Forecasts (ECMWF) Integrated Forecasting System (IFS) using the 4-D-VAR method, while Yumimoto et al. (2008) used the same approach to assimilate satellite lidar profiles in the RAMS/CFORS-4-D-VAR (RC4) model. Sequential assimilation approaches are also documented: optimal interpolation used by, for example, Collins et al. (2001) and Rasch et al. (2001) in the Model of Atmospheric Transport and Chemist (MATCH) and (Tombette et al., 2009) in the Polyphemus system; or the ensemble Kalman filter used by, for example, Sekiyama et al. (2010) in the Model of Aerosol Species in the Global Atmosphere (MASINGAR), Schutgens et al. (2010) in the SPRINTARS model, Pagowski and Grell (2012) in the WRF-Chem model, Dai et al. (2014) in the Non-hydrostatic ICosahedral Atmospheric Model (NICAM) and Rubin et al. (2016) in the Ensemble Navy Aerosol Analysis Prediction System/Data Assimilation Research Testbed (ENAAPS-DART) system.
In this study, we describe the development of the AOD assimilation module in the chemistry transport model (CTM) MOCAGE (e.g. Josse et al., 2004; Sič et al., 2015, Modèle de Chimie Atmosphérique à Grande Echelle). Our goal is to assimilate the regular daily global mapping of the 2-D column AOD by the National Aeronautics and Space Administration (NASA) Terra and Aqua satellites (Remer et al., 2005) with the 3-D CTM modelling of the major tropospheric aerosols. We use the variational 3-D-FGAT (first guess at appropriate time) method (Andersson et al., 1998), which is implemented in the CTM using the PALM coupler (Buis et al., 2006; Massart et al., 2007, Projet d'Assimilation par Logiciel Multi-Méthodes). The assimilated fields can then be evaluated independently against a large range of aerosol properties (2-D and 3-D) measured by other satellites and in situ and ground-based instruments. We will estimate improvements in the CTM modelling of all aerosol types achieved by the AOD assimilation compared to a direct (unassimilated) model run. One focus will be on the potential to improve air quality forecasting. Another will be how the continuous multicycle AOD assimilation can influence the modelled aerosol vertical distribution. To obtain an extensive validation dataset, we choose the 2012 summer field campaign of TRAQA (TRAnsport à longue distance et Qualité de l'Air dans le bassin méditerranéen) and centre our modelling on the western Mediterranean basin. The TRAQA campaign was a pre-ChArMEx (CHemistry and AeRosol MEditerranean EXperiment) experiment with the objective to characterize the air quality in the western Mediterranean basin (Attié et al., 2016). The validation data not only include the TRAQA measurements (in situ aircraft and balloon measurements of size-resolved and speciated aerosols), but also different remote-sensed AOD observations from the ground (Aerosol Robotic Network, AERONET; Holben et al., 1998) and satellite (Spinning Enhanced Visible and InfraRed Imager, SEVIRI; Thieuleux et al., 2005b).

This paper is organized as follows. In Sect. 2 we describe the MOCAGE CTM and its aerosol module, in Sect. 3 the data assimilation system and in Sect. 4 and Sect. 5, respectively, the assimilated and the independent observational data. Results from the assimilation model and its critical evaluation against the direct forecasts of the CTM with independent data are presented in Sect. 6. In Sect. 7 we discuss the overall performance of our assimilation system, and in Sect. 8 our recommendations for future work.

\section{Model description}

MOCAGE is a global CTM developed in Météo-France. It serves as an operational air quality model and simulates gases (Josse et al., 2004; Dufour et al., 2005) and primary (directly emitted) aerosols (Martet et al., 2009; Sič et al., 2015). It transports atmospheric species by a semi-Lagrangian advection scheme (Williamson and Rasch, 1989). Turbulent 
Table 1. Bin ranges of individual primary aerosol species present in MOCAGE.

\begin{tabular}{lllllll}
\hline & Bin 1 & Bin 2 & Bin 3 & Bin 4 & Bin 5 & Bin 6 \\
\hline Desert dust $(\mu \mathrm{m})$ & $0.1-1$ & $1-2.5$ & $2.5-5$ & $5-10$ & $10-30$ & $30-100$ \\
Sea salt $(\mu \mathrm{m})$ & $0.003-0.13$ & $0.13-0.3$ & $0.3-1$ & $1-2.5$ & $2.5-10$ & $10-20$ \\
Black carbon $(\mu \mathrm{m})$ & $0.0001-0.001$ & $0.001-0.003$ & $0.003-0.2$ & $0.2-1$ & $1-2.5$ & $2.5-10$ \\
Organic carbon $(\mu \mathrm{m})$ & $0.0005-0.003$ & $0.003-0.1$ & $0.1-0.3$ & $0.3-1$ & $1-2.5$ & $2.5-10$ \\
\hline
\end{tabular}

diffusion is implemented following Louis (1979), and convection is implemented following Bechtold et al. (2001). The dynamics within the CTM are forced by meteorological analysis fields (pressure, winds, temperature, specific humidity) from ARPEGE, the operational numerical weather prediction model of Météo-France. MOCAGE has 47 vertical hybrid sigma-pressure levels from the surface up to $5 \mathrm{hPa}$. The vertical resolution varies with altitude, with a resolution of $40 \mathrm{~m}$ in the planetary boundary layer, about $400 \mathrm{~m}$ in the free troposphere and about $700-800 \mathrm{~m}$ in the upper troposphere and lower stratosphere. The version of the model used in this study is described in Sič et al. (2015), and has been evaluated with a range of different remote-sensed and in situ measurements for cases and regions relevant to this study.

The model can include nested domains over smaller regions. In this study, the model is run in a two-domain configuration with a global grid of $2^{\circ} \times 2^{\circ}$ and a smaller nested domain (MEDI02) with a grid of $0.2^{\circ} \times 0.2^{\circ}$ over the Mediterranean basin and the Sahara. The MEDI02 domain, where we assimilate AOD data, has boundaries $20^{\circ} \mathrm{W}-40^{\circ} \mathrm{E}, 16-$ $52^{\circ} \mathrm{N}$. The lateral boundary conditions for aerosols are provided by the global domain.

Aerosols in MOCAGE consist of externally mixed primary aerosol species. Implemented species for this study are desert dust, sea salt, black carbon (BC) and organic carbon (OC). The particle size distribution for each type is divided into six size bins, characterized by the particle average diameter and mass. The size ranges of bins for all considered aerosol species are shown in Table 1. Each aerosol bin is then treated as a passive tracer: aerosols are emitted, transported and removed from the atmosphere; however there are no transformations or chemical reactions between aerosol types, between size bins or with gases. The aerosol dry deposition scheme is described in Nho-Kim et al. (2004). The sedimentation is implemented as described in Seinfeld and Pandis (1998). For the wet deposition, the model uses Giorgi and Chameides (1986) for the implementation of the in-cloud scavenging, and Slinn (1977) for the rain and snowfall below-cloud scavenging.

The emission inventories for $\mathrm{BC}$ and $\mathrm{OC}$ are prepared as follows. The anthropogenic component comes from Lamarque et al. (2010) for both domains (Global and MEDI02). This inventory is defined monthly, and harmonized for the year 2000 (Lamarque et al., 2010). Biomass burning (BB) sources of $\mathrm{BC}$ and $\mathrm{OC}$ aerosols are introduced into the model with a daily frequency from the Global Fire Assimilation System (GFAS) version 1.1 (Kaiser et al., 2012). The GFAS assimilates the fire radiative power observed by MODIS, corrects the cloud cover gaps, filters anthropogenic and volcanic activities and finally calculates daily biomass burning aerosol emissions for BC and OC. We use daily BB emissions for better synoptic forecasts, which is not possible with the monthly mean emissions of Lamarque et al. (2010).

Sea salt particles are emitted using the semi-empirical source function from Jaeglé et al. (2011), which includes a particle size, wind speed, and sea surface water temperature dependence. Desert dust aerosols are emitted by a dynamical online scheme, which depends on the wind intensity and surface characteristics. The scheme is based on Marticorena et al. (1997). It covers Africa, Arabia and the Middle East $\left(13-36^{\circ} \mathrm{N}, 17^{\circ} \mathrm{W}-77^{\circ} \mathrm{E}\right)$, where input soil properties and aerodynamical surface parameters have a resolution of $1^{\circ} \times 1^{\circ}$ (Marticorena et al., 1997), and north-eastern Asia $\left(35.5-47^{\circ} \mathrm{N}, 73-125^{\circ} \mathrm{E}\right)$ with the input parameter resolution of $0.25^{\circ} \times 0.25^{\circ}$ (Laurent et al., 2006).

\section{Description of data assimilation system}

The data assimilation system used in this study is MOCAGEValentina, developed jointly by Météo-France and CERFACS (Centre Européen de Recherche et de Formation Avancée en Calcul Scientifique). The assimilation algorithm used is 3-D-FGAT (3-D first guess at appropriate time; Fisher and Andersson, 2001; Massart et al., 2010), which is a compromise between the 3-D-Var and 4-D-Var methods. Observations are taken at their exact times to the nearest minute; i.e. every measurement is compared with the background at the time of measurement, as in 4-D-Var. The optimal analysis is estimated only for a specified moment in the assimilation cycle, as in 3-D-Var, and not for the whole trajectory, as in 4-D-Var. Thus, compared to 4-D-VAR, during the assimilation the information given by observations is not propagated in time, and consequently we do not need the linearized operator of the model evolution and its adjoint (Courtier et al., 1994).

The goal of the variational assimilation process is to minimize the cost function, whose incremental form in 3-DFGAT is 


$$
\begin{aligned}
J(\delta x)= & J_{\mathrm{b}}(\delta x)+J_{\mathrm{o}}(\delta x)=\frac{1}{2} \delta x^{\mathrm{T}} \mathbf{B}^{-1} \delta x \\
& +\frac{1}{2} \sum_{i=0}^{N}\left(d_{i}-\mathbf{H}_{i} \delta x\right)^{\mathrm{T}} \mathbf{R}_{i}^{-1}\left(d_{i}-\mathbf{H}_{i} \delta x\right)
\end{aligned}
$$

where $J_{\mathrm{b}}$ is a part of the cost function related to the background; $J_{\mathrm{O}}$ is a part of the cost function related to the observations; $\delta x=x-x^{\mathrm{b}}$ is the misfit between the background $x^{\mathrm{b}}$ and the state of the system $x ; d_{i}=y_{i}-H_{i} x^{\mathrm{b}}\left(t_{i}\right)$ is the innovation and represents the distance of the observation $y_{i}$ from the background $x^{\mathrm{b}}$ at time $t_{i} ; H_{i}$ is the non-linear observation operator; $\mathbf{H}$ is its linearized version (the tangent-linear); $\mathbf{B}$ is the background error covariance matrix; and $\mathbf{R}_{i}$ is the observation error covariance matrix at time $t_{i}$. The matrices $\mathbf{B}$ and $\mathbf{R}_{i}$ influence the weighting of the terms $J_{\mathrm{b}}$ and $J_{\mathrm{o}}$.

To find the optimal solution we minimize the cost function $J$ by computing its gradient:

$\nabla J(\delta x)=\mathbf{B}^{-1} \delta x+\sum_{i=0}^{N} \mathbf{H}_{i}^{\mathrm{T}} \mathbf{R}_{i}^{-1}\left(d_{i}-\mathbf{H}_{i} \delta x\right)$.

After estimating the analysis increment $\delta x^{\mathrm{a}}$, we add it to the aerosol abundance at the beginning of the cycle. The model is then run over a cycle length $(1 \mathrm{~h})$ to obtain the analysed trajectory. Its endpoint is used as the initial background field for the next cycle.

\subsection{Preconditioning}

MOCAGE-Valentina uses the incremental form of 3-DFGAT (Eq. 1). In order to minimize the cost function more efficiently and to improve convergence, the increment $\delta x$ is preconditioned by

$v=\mathbf{B}^{-\frac{1}{2}} \delta x$.

In this way the cost function becomes

$$
J(x)=\frac{1}{2} v^{\mathrm{T}} v+\frac{1}{2} \sum_{i=1}^{N}\left(d_{i}-\mathbf{H}_{i} \mathbf{B}^{\frac{1}{2}} v\right)^{\mathrm{T}} \mathbf{R}_{i}^{-1}\left(d_{i}-\mathbf{H}_{i} \mathbf{B}^{\frac{1}{2}} v\right),
$$

and its gradient is

$\nabla J(\delta x)=v+\left(\mathbf{B}^{\frac{1}{2}}\right)^{\mathrm{T}} \sum_{i=1}^{N} \mathbf{H}_{i}^{\mathrm{T}} \mathbf{R}_{i}^{-1}\left(d_{i}-\mathbf{H}_{i} \mathbf{B}^{\frac{1}{2}} v\right)$.

In this formulation, there is no need for an explicit specification of the inverse matrix $\mathbf{B}^{-1}$, and the preconditioning reduces the number of iterations (Courtier et al., 1994). In MOCAGE-Valentina, the cost function is minimized using the limited-memory BFGS (Broyden-Fletcher-GoldfarbShanno) method (Liu and Nocedal, 1989).

The minimization of the cost function with the preconditioned form gives an increment of the analysis in the space of the variable $v$, which after the minimization is converted back to model space:

$\delta x=\mathbf{B}^{\frac{1}{2}} v$.

More details on the assimilation algorithm are provided by Pannekoucke and Massart (2008) and Massart et al. (2012).

\subsection{The control variable}

For aerosols, the modelled prognostic variables (i.e. the 3$\mathrm{D}$ concentration of aerosols of different composition) and the observations (i.e. the column optical depth summed over all aerosols at visible wavelengths such as $550 \mathrm{~nm}$ AOD) are usually not the same physical quantity. In the case of AOD observations, to define which variable will be minimized, different choices are possible. A straightforward choice is to use a prognostic variable as a control variable, as implemented by Liu et al. (2011). Following this approach in our system, the control variable would correspond to a 4-D variable containing the 3-D fields of all 24 aerosol bins. The matrix B would have to include the variances and covariances of all bins separately. This could be difficult to define, but the analysis would be partitioned automatically into all bins by the system.

Benedetti et al. (2009) made the choice to use the 3-D total aerosol concentration as the control variable. This makes the control variable smaller, corresponding to a 3-D variable, where all bins are merged into a single one. Considering the characteristics of our system, we decided to follow the same approach as in Benedetti et al. (2009). Compared to the Liu et al. (2011) approach, the problem of minimization of the cost function is better determined: the 2-D AOD observations constrain one 3-D variable as the unknown, compared to 24 3-D variables as unknowns in the Liu et al. (2011) approach. The matrix $\mathbf{B}$ does not have to be defined for all bins separately, nor does it need to contain the inter-bin covariances. Nevertheless, in order to linearize the observation operator, it is necessary to decide how the analysis increment $\delta x^{\mathrm{a}}$ will influence each bin. The increment could be weighted by different quantities, like number or mass concentration, or extinction coefficient. The real contribution of different aerosol types in the increment is unknown, and we can only rely on the model information. In this way, all repartition weights based on the model stay biased in a similar way compared to the real repartition weights, regardless of the choice of the repartition. Considering all possible choices and the characteristics of our system, we decided to keep the relative mass contributions of all bins constant (24 bins including 6 size bins of all 4 aerosol types). After the analysis increment is calculated, it is repartitioned to the different bins in the model according to their background fractions of the total aerosol mass. 


\subsection{The observation operator}

The assimilation of AOD in MOCAGE-Valentina requires the development of an observation operator $(H)$, which transforms the control variable from the model space, i.e. the total 3-D concentration, into the observation space, i.e. AOD. The AOD $(\tau)$ is calculated by taking into account bin number concentrations ( $\left.n_{\text {bin }}\right)$ of all bins (types included) at a certain model level and the optical properties of individual species calculated by the Mie code:

$H x=\sum_{\text {bin }} \sum_{\text {lev }} C_{\text {ext }}\left(D_{\mathrm{p}}, \tilde{n}, \lambda\right) \Delta z_{\text {lev }} n_{\text {bin }}=\tau$,

where $\Delta z_{\text {lev }}$ is the vertical thickness of the model level "lev" (m), and $C_{\text {ext }}$ is the extinction cross-section $\left(\mathrm{m}^{-1}\right)$. To calculate $C_{\text {ext }}$ in the model we use Wiscombe's Mie code scheme for spherical homogeneous particles (Wiscombe, 1979, revised 1996, 1980) and aerosol refractive indices from the Global Aerosol Data Set/Optical Properties of Aerosols and Clouds (GADS/OPAC, Köpke et al., 1997; Hess et al., 1998) and Kirchstetter et al. (2004). We also take into account the hygroscopicity of sea salt aerosols.

The tangent-linear operator $\left(\mathbf{H}=\frac{\partial H}{\partial x_{i}}\right)$ is a linearized version of the non-linear observation operator $H$ around the system state $x$, and it consists of partial derivatives of $H$ with respect to all input variables. It gives a first-order approximation $(\delta \tau)$ of the difference between the unperturbed $(H x)$ and the perturbed results $(H(x+\Delta x))$ of the non-linear operator $H$.

The tangent linear operator can be derived explicitly by the finite-difference method, but it is a computationally expensive method. Instead, the tangent-linear operator can be considered as a sequence of linearized sub-operators of the non-linear observation operator and built piece by piece by differentiating each line of code or loop separately. This approach allows the parts of the code to be tested separately. In order to provide a linearized trajectory around the model state $x$, the tangent linear operator has to satisfy

$\lim _{\delta x \rightarrow 0} \frac{H(x+\delta x)-H x}{\mathbf{H} \delta x}=1$.

As long as the perturbation $\delta x$ is small enough that the perturbed state $x+\delta x$ stays close to the model state $x$, the test will give a value close to 1 .

The adjoint operator $\left(\mathbf{H}^{\mathrm{T}}\right)$ is the transpose of the tangentlinear operator, and it satisfies

$$
\langle\mathbf{H} x, y\rangle=\left\langle x, \mathbf{H}^{\mathrm{T}} y\right\rangle,
$$

where $\langle x, y\rangle$ represents the inner product of $x$ and $y$. Analogously to the tangent linear operator, the adjoint operator can be considered as a sequence of operators. Each discrete operation in the tangent linear operator has a corresponding operation in the adjoint operator, but the order of execution is reversed.

\subsection{The error covariance matrices}

The background error covariance matrix is a key component of the data assimilation system. It defines the background errors and the spatial structure of the analysis. The background error covariance matrix $\mathbf{B}$ is a matrix of size $j \times j$, where $j$ is the size of the control variable. It can be represented as

$\mathbf{B}=\mathbf{\Xi} \mathbf{C} \mathbf{\Xi}^{\mathrm{T}}$,

where $\boldsymbol{\Xi}$ is the diagonal matrix of the square root of the variances, and $\mathbf{C}$ is the positive definite symmetric matrix of correlations. In the case of the preconditioned cost function, the matrix is formulated as

$\mathbf{B}^{\frac{1}{2}}=\mathbf{\Xi} \mathbf{C}^{\frac{1}{2}}$

where $\mathbf{C}^{\frac{1}{2}}$ is the square root of the matrix $\mathbf{C}$. Because neither enough information is available to explicitly estimate all correlation members, nor is there enough memory to store them, the matrix $\mathbf{B}$ is modelled as an operator. To estimate the product of the matrix $\mathbf{B}$ and a vector, MOCAGE-Valentina uses the integration of a generalized diffusion-type equation in a reduced space (Weaver and Courtier, 2001).

The observation error covariance defines the observation and representativeness errors. In our study we neglect the observation error correlations, which means that all nondiagonal members (covariances) in the matrix $\mathbf{R}$ are zero. The matrix $\mathbf{R}$ is reduced to its diagonal with the variances of measurements:

$\mathbf{R}=\mathbf{D}_{y}=\operatorname{diag}\left(\sigma_{\mathrm{obs}}^{2}\right)$.

The background and observation error variances, located along the diagonal of $\mathbf{B}$ and $\mathbf{R}$, influence the weight of the model and observations in the cost function. In this study, we specified them as a percentage of the first guess field for the background error variance and a percentage of each measured AOD for the observation error variance. From the published MODIS uncertainties we estimated the percentage for the errors of the ("super-")observations to be $12 \%$. Further, we used the $\chi^{2}$ diagnostics to estimate optimal values for the B error variances (Ménard et al., 2000; Talagrand, 2003). The $\chi^{2}$ test is an a posteriori diagnostic, which allows us to check that the errors are properly specified. It checks whether, for each assimilation window, it is true that

$E\left(\frac{2 J_{\min }}{p}\right) \sim 1$,

where $E$ is the expectation (statistical average), $J_{\min }$ is the value of the cost function at the minimum and $p$ is the number of observations. For this test, it is necessary to run the assimilation system for a prolonged period of time and, in the case of sufficient number of observations, the matrix $\mathbf{B}$ will not depend on its initial value any more. Because this method is computationally expensive, a very rigorous optimization of 
the errors is difficult to do. Therefore, we carried out several test runs to determine optimal parameters for the matrices a posteriori. As the optimal parameters, we estimated that the percentage for the errors of the model should be twice as large as for the observations ( 24 and $12 \%$ respectively).

Missing secondary aerosols in MOCAGE are considered as a possible underestimation of AOD in the model, and this is taken into account in the covariance matrices error definitions. Therefore, the possibly smaller AOD values of the background are compensated by a higher percentage for the error of the model. In addition, it is considered that it is better to have overestimated errors in the matrix $\mathbf{B}$ than vice versa (Talagrand, 2003).

Covariances of the background error matrix, which influence the spread of the analysis to neighbouring grid boxes, are specified with constant correlation lengths in the horizontal and the vertical. The constant and homogeneous correlation lengths are modelled using a Gaussian function (Pannekoucke and Massart, 2008) in terms of distance in kilometres for the horizontal lengths, and in terms of number of model levels for the vertical lengths (Massart et al., 2009). The implemented horizontal correlation length is $45 \mathrm{~km}$. For the vertical correlation, with the column-integrated observations, there is no explicit need for vertical correlation elements. However, in the matrix $\mathbf{B}$ preconditioned cost function (Eq. 13) it is advantageous not to have null vertical correlation lengths. Therefore, we apply a vertical correlation of one model level. The type of the correlation field influences the method by which the generalized diffusion-type equation is solved. In the case of constant correlation lengths in the limited-area domain, the equation is solved by the finitedifference method.

\section{Assimilated observations}

The MODIS (Moderate-resolution Imaging Spectroradiometer) instruments observe atmospheric aerosols on board Terra (since 2000) and Aqua (since 2002) from complementary sun-synchronous orbits. The Terra overpass time is around 10:30 local solar time at the Equator in its descending (daytime) node, and the Aqua overpass time is around 13:30 local solar time at the Equator in the ascending node. We use MODIS Aerosol Optical Depth Collection C051 retrievals at $550 \mathrm{~nm}$ from Terra and Aqua, the ocean product retrieved with the "best solution" and the reflectance-corrected land product. Their predicted uncertainties are $\Delta \tau= \pm(0.03+$ $0.05 \tau)$ over oceans and $\Delta \tau= \pm(0.05+0.15 \tau)$ over land (Remer et al., 2005). Over bright desert areas, we use the "Deep Blue" MODIS product (Hsu et al., 2006). For the assimilation, we only considered the best quality data, with the highest possible quality flag.

MODIS L2 resolution of $10 \mathrm{~km} \times 10 \mathrm{~km}$ is approximately 2 times finer than the model resolution of $0.2^{\circ} \times 0.2^{\circ}$ over the control MEDI02 domain in which the assimilation is per- formed. We have no way of treating two separate AOD values within a model grid cell at about the same time, and so just average all observations in each grid cell that occur on the same swath (making so-called super-observations; Daley, 1993). Modelled and observed AODs are then on the same 2$\mathrm{D}$ grid, and the maximal number of observations per $1 \mathrm{~h}$ slot over the whole domain is reduced in this way from $\approx 80000$ to $\approx 15000$. MODIS data from the Terra and Aqua platforms are separated in time, except at high latitudes (not used here), and all AODs are binned in the MEDI02 grid at 5 min intervals.

\section{Independent observations for evaluation}

\subsection{SEVIRI}

SEVIRI (Spinning Enhanced Visible and InfraRed Imager) geostationary observations over oceans are retrieved at $550 \mathrm{~nm}$ by Thieuleux et al. (2005b). The ICARE data centre operationally implemented this algorithm and makes AOD data available on its website (www.icare.univ-lille1.fr). This product was evaluated against other satellite products and AERONET measurements by Thieuleux et al. (2005b) and Breon et al. (2011). The instrument makes an image of the whole Earth disk every $15 \mathrm{~min}$ as seen from the equatorial geostationary orbit and at a longitude of $0^{\circ}$. We sample the SEVIRI AOD every hour, and only use data over water, since the retrieval over dark surfaces is usually more accurate. The nadir horizontal resolution is $3 \mathrm{~km}$, while over Europe it is $\approx 5 \mathrm{~km}$, and we average the SEVIRI AOD data that fall within the same modelled grid box.

\subsection{AERONET}

AERONET (Aerosol Robotic Network) measures groundbased AOD from hundreds of automated stations in the world with an accuracy of \pm 0.01 for a range of wavelengths (Holben et al., 1998). We use all available L2 data from different stations, and interpolate these data in logarithmic space to $550 \mathrm{~nm}$ (to harmonize wavelengths between different stations and with the model) by using available neighbouring wavelengths: $440,500,675$ and $870 \mathrm{~nm}$.

\subsection{In situ observations from the TRAQA campaign}

TRAQA (TRAnsport à longue distance et Qualité de l'Air dans le bassin méditerranéen) was a scientific project including a measurement campaign intended as a pre-ChArMEx (CHemistry and AeRosol MEditerranean EXperiment) experiment (http://charmex.lsce.ipsl.fr). It took place over the north-western Mediterranean basin during the northern summer of 2012. The main objectives of TRAQA were studies of transport, ageing and mixing of the polluted air masses in and around the Mediterranean basin and their impact on air quality. From 26 June to 11 July seven intensive obser- 
vation periods were conducted with the ATR-42 aircraft of Météo-France; atmospheric balloons (sounding and drifting) and ground instruments measured trace gases and aerosols. During the campaign, a desert dust outbreak from Africa transported aerosols to the Mediterranean basin. It was well observed around 29 June with several different instruments (Attié et al., 2016).

\subsubsection{PCASP}

In our study, we use the data measured by the passive cavity aerosol spectrometer probe (PCASP), which was on board the ATR-42 aircraft. The PCASP measures the aerosol concentration and the aerosol size distribution with its 30 channels (Strapp et al., 1992). PCASP measures particles with diameters from 0.1 to $3 \mu \mathrm{m}$, with channel ranges, calibration methods and errors reported by Cai et al. (2013). The reported Poisson counting error is in the range 5-15\%. The high-frequency instrument data are averaged into $1 \mathrm{~min}$ intervals for model comparison, with a horizontal resolution of about $8 \mathrm{~km}$ at cruise speed.

\subsubsection{LOAC}

Finally, we also use data from LOAC (Light Optical Particle Counter) instruments (Renard et al., 2015) collected during TRAQA. LOAC is a light aerosol optical counter measuring aerosol number concentration in 20 size classes within a diameter range from 2 to $100 \mu \mathrm{m}$ in the version of the instrument used in the TRAQA campaign. The uncertainty for total concentration measurements is $\pm 20 \%$ when concentrations are higher than $1 \mathrm{~cm}^{-3}$ and up to about $\pm 60 \%$ when concentrations are smaller than $10^{-2} \mathrm{~cm}^{-3}$. LOAC uses the technique of measuring aerosol at two scattering angles (Lurton et al., 2014; Renard et al., 2015). During TRAQA, LOAC was mounted on meteorological sounding balloons, where its vertical resolution depends on measurement frequency. The processed data that we use in our analysis have a vertical resolution in the troposphere of about 0.3 to $0.4 \mathrm{~km}$, which is similar to the model resolution.

\section{Results}

We run two MOCAGE configurations, one with and one without assimilation. The assimilation is performed in the regional MEDI02 domain. The simulation without assimilation is referred to as the direct model run and the simulation with assimilation as the assimilation model run. The simulated period for which we evaluate the model performance is for 19 days from 25 June until 13 July 2012. The model is run after a spin-up period of 45 days, where the last 10 days for the assimilation model run are the so-called assimilation spinup. The assimilation cycles in the experiment have a length of $1 \mathrm{~h}$. The cost function is minimized until the convergence criterion is reached, or when the maximum number of iter-

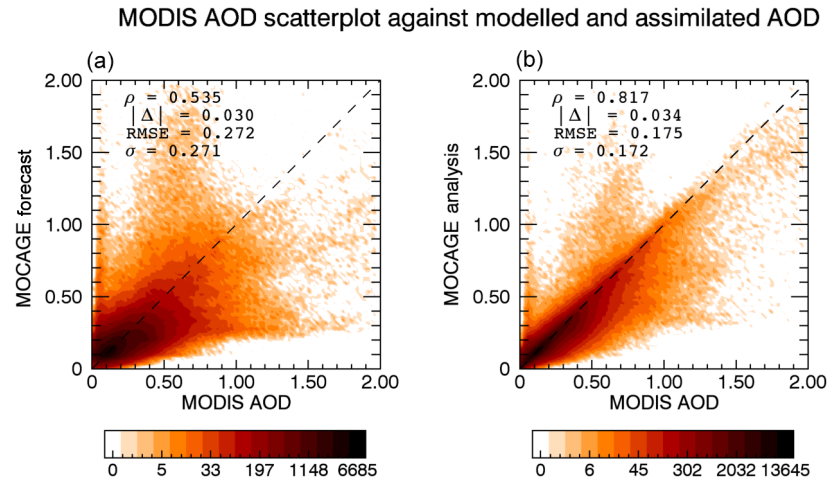

Figure 1. Scatter plots of aerosol optical depths (where colours represent the number of points) of assimilated MODIS observations and the $1 \mathrm{~h}$ assimilation forecast (first guess) (a), and the assimilation analysis (b) for each $1 \mathrm{~h}$ assimilation window (both runs start from the same assimilated conditions of $1 \mathrm{~h}$ before). In each panel, correlation $(\rho)$, absolute bias $(\Delta)$, root mean square error (RMSE) and standard deviation $(\sigma)$ are noted. The assimilated data correspond to the period of the TRAQA campaign from 25 June until 13 July 2012, and cover the MEDI02 domain.

ations of 200 is reached. The analysis increment is added at the beginning of each assimilation cycle.

\subsection{Performance of the assimilation}

In Fig. 1 we evaluate the impact of the data assimilation on the modelled fields (the $1 \mathrm{~h}$ assimilation forecast for the each $1 \mathrm{~h}$ assimilation cycle and the corresponding assimilation analysis) by comparing each of them directly with the observations which we assimilated, and this should be considered as a "sanity" check of the system. The figure represents the performance of the assimilation system and its ability to move the modelled field closer to the observed values. The assimilated model can more readily lower the overestimated values than elevate the underestimated values. The statistics of the scatter plots against assimilated observations show increased correlation (from 0.54 for the modelled fields to 0.82 for the assimilated fields), lowered root mean square error (from 0.27 to 0.18 ) and lowered standard deviation (from 0.27 to 0.17 ), demonstrating what we expect from assimilation. Similar values of the root mean square error and the standard deviation show the absence of important biases in the system.

\subsection{Comparison with SEVIRI}

The period of the TRAQA campaign is marked by two desert dust events coming from Africa. In the western Mediterranean basin, where the campaign took place, this produces elevated concentrations of desert dust aerosols from the Sahara desert. Figure 2 shows the desert dust event in the Mediterranean basin on a particular day (29 June) seen by the direct model run, the assimilation model run and the 

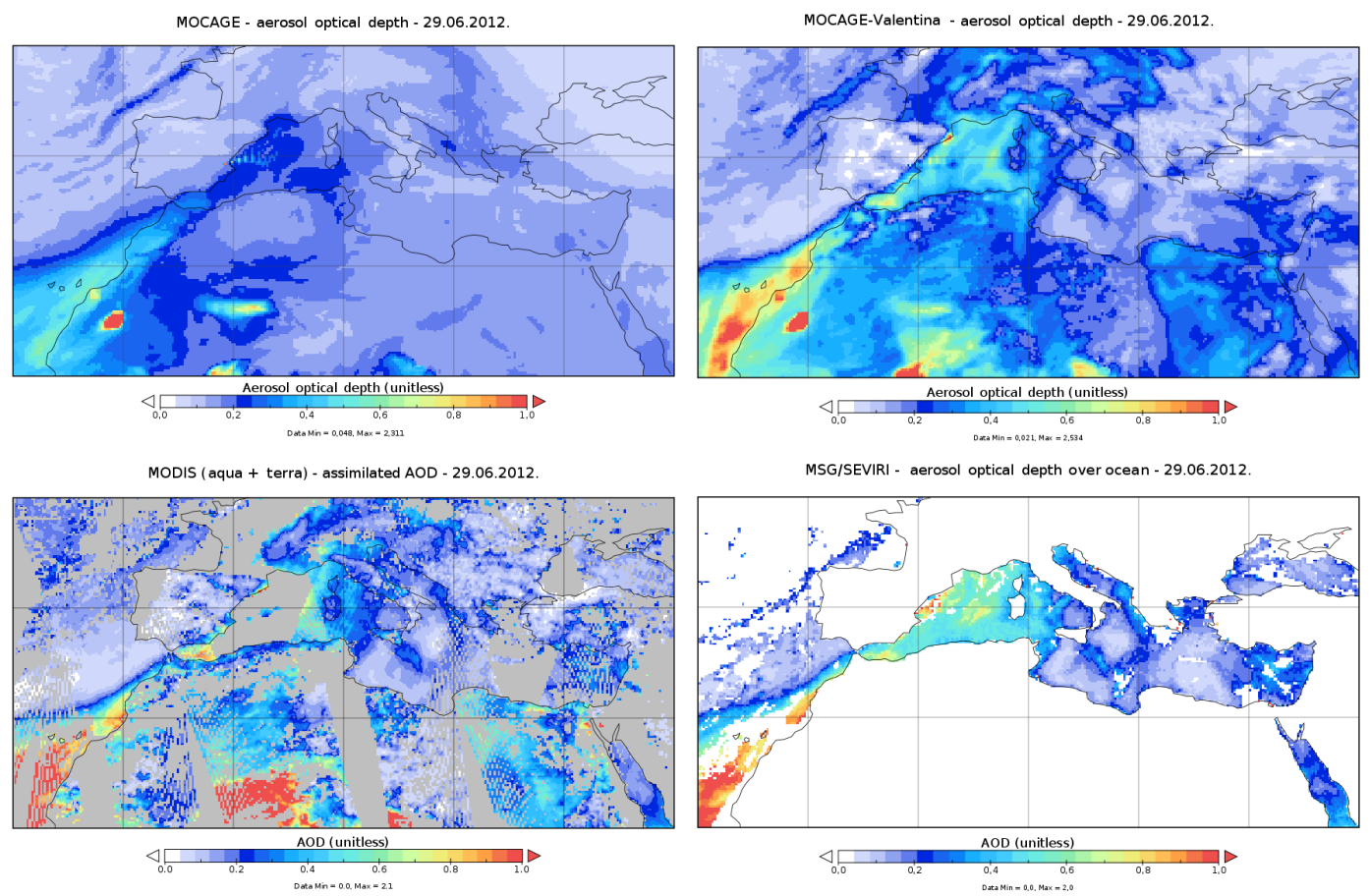

Figure 2. The aerosol optical depth over Europe on 29 June 2012 at 12:00 UT, (top left) simulated in MOCAGE by the model direct run; (top right) simulated in MOCAGE by the MODIS assimilation model run; (bottom left) observed by MODIS (Aqua + Terra) and used for assimilation in MOCAGE (shown observations are collected during the whole day, and not only at 12:00); and (bottom right) observed by SEVIRI, which serves as an independent dataset. The colours from white to red represent AOD from low to high values.

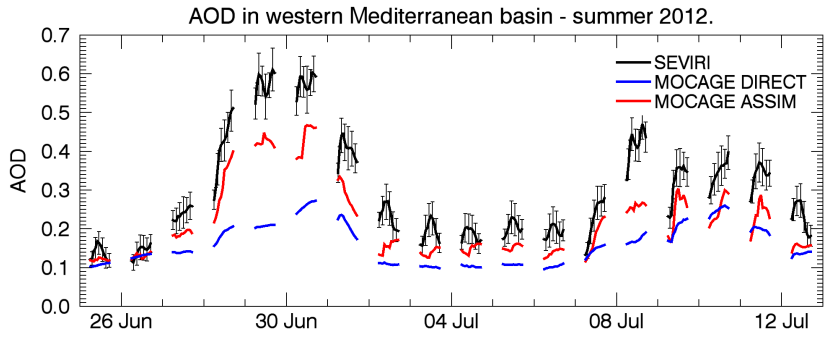

Figure 3. Hourly time series of aerosol optical depth at $550 \mathrm{~nm}$ of SEVIRI data (black), the direct model (blue) and the assimilation model run (red) over the western Mediterranean $\left(0-10^{\circ} \mathrm{E}, 35-\right.$ $45^{\circ} \mathrm{N}$ ) for the period of the TRAQA campaign from 25 June until 13 July 2012. The considered region is also marked in Fig. 5 by the grey box. Correlation, bias and root mean square error for both the direct model and the assimilation model run as compared to SEVIRI data are given in Table 2.

MODIS and SEVIRI instruments, and it illustrates the impact of the assimilation on the modelled field. We look at a longer time period in Fig. 3, which represents the time series of the direct and assimilation model runs and the independent SEVIRI observations over the western Mediterranean basin. Table 2 shows the statistics corresponding to this figure. The two desert dust events in the figure are highlighted with high values of AOD ( $>0.25)$. The first, stronger dust outbreak in- creases AOD values during 4 to 5 days over the region (from 27 June to 1 July). Its extent is well simulated in the model direct run, but its intensity is underestimated (Fig. 2). The assimilation produced fields that are closer to the SEVIRI observations. The second desert dust event occurs at the end of the TRAQA period (from 8 to 11 July). It is weaker than the first one and only localized in the part of the western Mediterranean closer to the coast of Africa. The AOD values of the second dust event, and also of the period between the two events, are underestimated in the direct model run, although not as strongly as during the first event. Data assimilation reduces the difference between the model and the observations, improving all statistical parameters (Table 2). For example, the correlation improves from 0.83 for the direct model to 0.96 for the assimilated model run. Each of the two MODIS instruments overpasses each point once during the daytime (one at approximately 10:30 and another at $\approx 13: 30$ in local solar time), and this provides sufficient information to even improve the hourly AOD variation in the assimilated field during different dates (for example, 9-11 July; Fig. 3).

Figure 4 compares AOD from the direct and the assimilation model runs with SEVIRI observations over the whole control domain, and not only over the western Mediterranean. The majority of the observed points correspond to small AOD values where the direct model and the observations agree well. For larger observed values, the scatter plots 
Table 2. Correlation $(\rho)$, absolute bias $(\Delta)$ and root mean square error (RMSE) between SEVIRI observations and MOCAGE direct/assimilation model run for the western Mediterranean during the TRAQA campaign between 25 June and 13 July 2012. The mean number of SEVIRI observations per hour is also given. The statistics correspond to Fig. 3 with the observations localized in the region 0 $10^{\circ} \mathrm{E}, 35-45^{\circ} \mathrm{N}$ (marked in Fig. 5 by the grey box).

\begin{tabular}{ccccc|ccc}
\hline & \multicolumn{4}{c}{ MOCAGE direct } & \multicolumn{3}{c}{ MOCAGE assimilation } \\
\cline { 2 - 8 } & $N_{\text {obs }}\left(\mathrm{h}^{-1}\right)$ & $\rho$ & $\Delta$ & RMSE & $\rho$ & $\Delta$ & RMSE \\
\hline SEVIRI & 20875 & 0.83 & 0.14 & 0.17 & 0.96 & 0.08 & 0.09 \\
\hline
\end{tabular}

\section{Summer 2012}
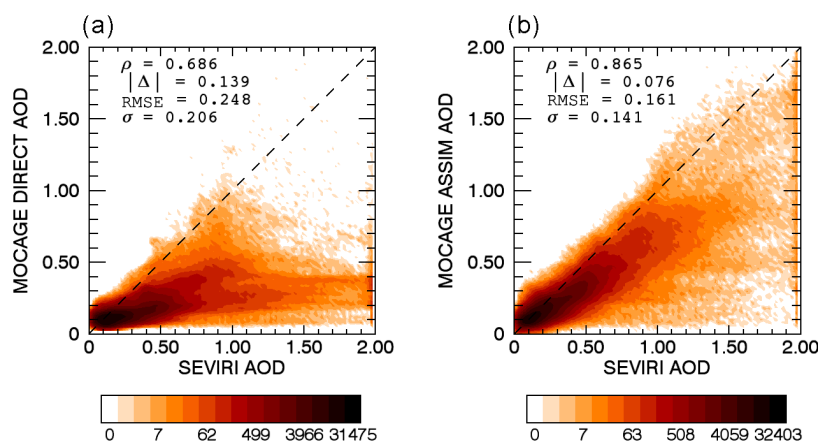

Figure 4. Scatter plots of aerosol optical depths (where colours represent the number of points) from the independent observation dataset (SEVIRI) and the simulations: the direct model run (a) and the assimilation model run (b). In each panel, correlation $(\rho)$, absolute bias $(\Delta)$, root mean square error (RMSE) and standard deviation $(\sigma)$ are noted. The included data correspond to the period of the TRAQA campaign from 25 June until 13 July 2012, and cover the whole MEDI02 domain.

confirm that the direct model run underestimated the AOD field, largely because the desert dust outbreaks were underestimated in the model. As expected, the assimilation reduced this disagreement, also displaying better statistics compared to the direct model run (e.g. the correlation improved from 0.69 to 0.87 )

\subsection{Comparison with AERONET}

We compare the model direct run and assimilation model run with the AOD data from AERONET stations. In total, we consider measurements from 35 AERONET stations, which are all in or around the Mediterranean basin. Their locations are presented in Fig. 5. Time series plots for eight stations are presented in Fig. 6, and the statistics for all stations in Table 3. The stations in Fig. 6 are chosen to representatively cover the basin. The time series of the stations in the western part of the Mediterranean basin and in Spain are marked by the strong desert dust event, which was already discussed earlier. Stations in Spain recorded the event before the stations in France, where it arrived a couple of days later. The dura-

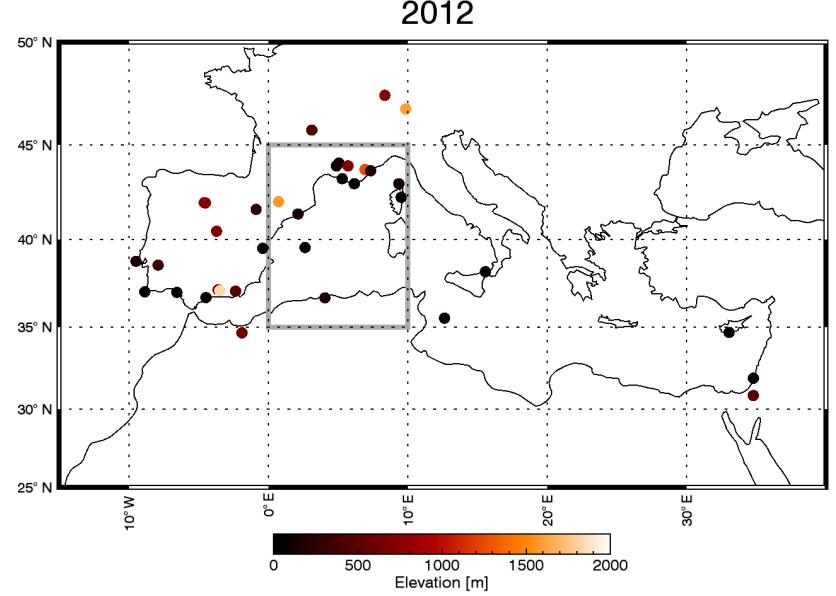

Figure 5. Positions of AERONET stations used in this study for the period of the TRAQA campaign in the northern summer of 2012. The grey box marks the region from which we considered SEVIRI data used in Fig. 3 and Table 2. The colours represent elevation of the stations as marked on the colour bar.

tion of the event is well simulated by both the direct model run and the assimilation model run in all stations, but the intensity is underestimated in the direct model run (Fig. 2). However, the assimilation model run matches the outbreak intensity well. The second, smaller desert dust event at the end of the TRAQA period is only observed at southern stations. Similarly, the assimilation model run corrects its intensity underestimated by the direct model run. The stations in the east, like in Lampedusa and Cyprus, were not influenced by these dust events. They are mostly influenced by sea salt aerosols, and the data assimilation also has a positive impact here. The assimilation model run, with only two MODIS overpasses per day, also shows improved hourly variations of AOD in these stations. These variations are not clearly visible in the model direct run, but they are present in AERONET data with similar amplitudes as in the assimilation model run. The statistics of all AERONET stations confirm the overall positive effect of assimilating MODIS data (Table 3).

The AERONET findings confirm those obtained by the comparison with SEVIRI observations. The scatter plot of all AERONET observations (Fig. 7) reinforces the conclusion that the assimilation model run reduces the bias in the AOD field of the direct model run and significantly improves the statistical parameters.

\subsection{In situ aircraft concentration measurements}

To further assess the performance of the assimilation model run we evaluate the impact of the AOD assimilation on aerosol properties other than AOD. To do this, we compare the modelled aerosol number concentrations with the aerosol concentrations measured in situ during the TRAQA period by the PCASP instrument. During the campaign, flights with 

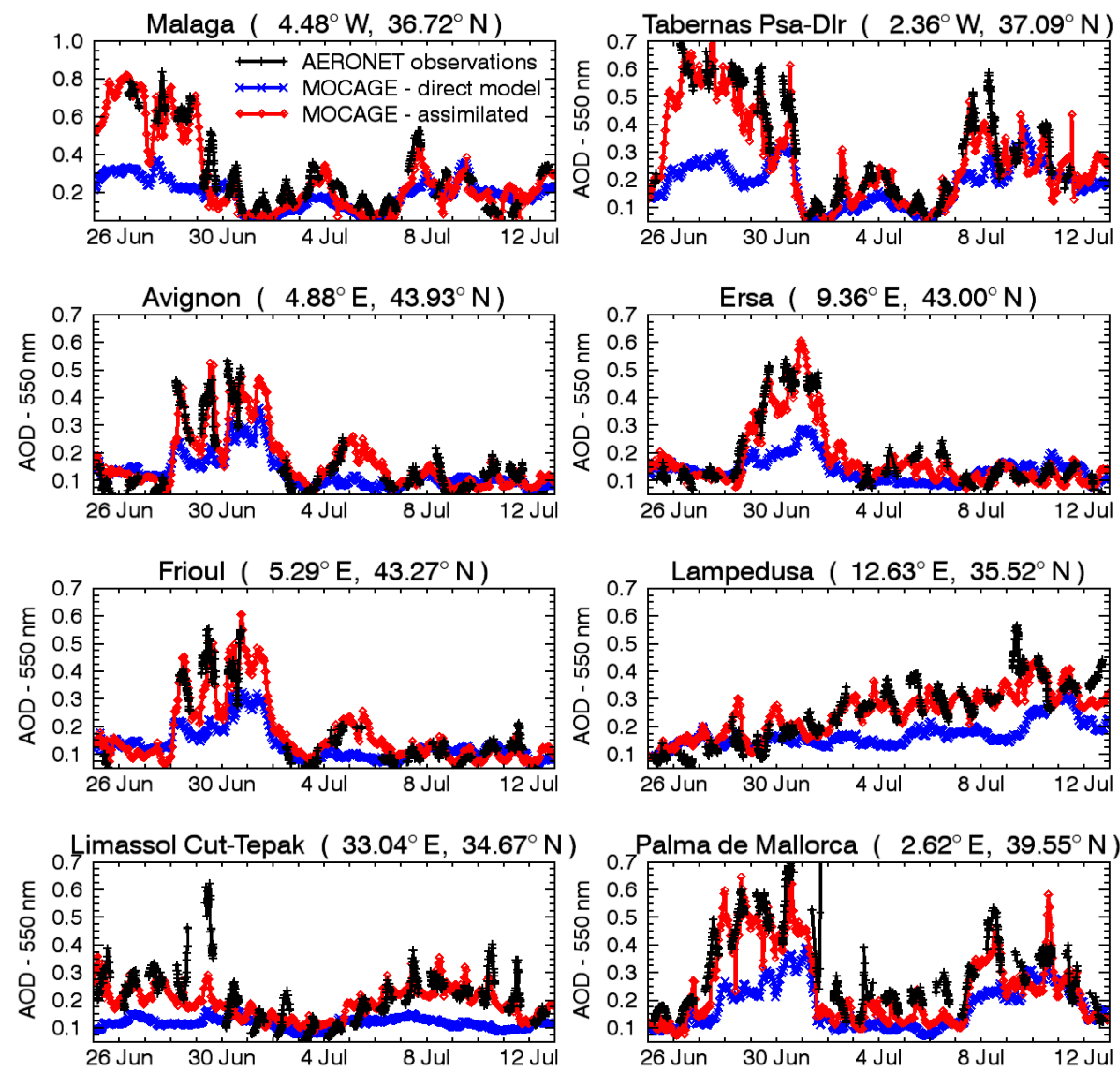

Figure 6. Time series of aerosol optical depth at $550 \mathrm{~nm}$ of the AERONET data (black line), the direct model (blue line) and the assimilation model run (red line) for the period of the TRAQA campaign from 25 June until 13 July 2012. The presented AERONET data are from eight stations: Malaga (ESP), Tabernas (ESP), Avignon (FRA), Ersa (FRA), Frioul (FRA), Lampedusa (ITA), Limassol (CYP), Palma de Mallorca (ESP). The location of a particular station is marked at the top of each panel. Correlation, bias and root mean square error for both the direct model and the assimilation model run as compared to the AERONET data are given in Table 3.

the ATR-42 were conducted during 9 different days, carrying the PCASP instrument on board. The flights passed over the whole western Mediterranean basin using Toulouse, Marseille and Corsica airports, and covered different meteorological and air quality conditions. Figure 8 presents three representative time series from these flights: flight A of 26 June 2012 from Corsica to Toulouse (Fig. 8a), flight B of 27 June 2012 from Marseille to Corsica and back to Toulouse (Fig. 8b) and flight $\mathrm{C}$ of 29 June 2012 from Corsica to Toulouse (Fig. 8c). Fig. 8d show the tracks of the flights and the availability of the MODIS observations for each day of the flight. The data availability helps to understand the most recent impact of the observations in the model, but one should carefully regard it since it does not reflect the influence of the assimilated observations during the days prior to the flights.

During flight A (Fig. 8a), aerosol concentrations are rather low, except for the anthropogenic pollution around Toulouse measured at the flight end. The aircraft first visited the area of the Gulf of Genoa where, because of no available AOD ob- servations, the direct model run and the assimilation model run show the same aerosol concentrations. The variability in that part of the flight is well simulated, with slightly higher modelled aerosol concentrations at these heights than what is measured. Later, on the way to Toulouse, with more available satellite observations, the assimilation model run lowers AOD and approaches the measured concentration values. With situations of no observations or with sparse ones, data assimilation is not able to have a major effect.

Following the path of flight B (Fig. 8b) we see again rather clean aerosol conditions. The modelled and assimilated curves differ, and the assimilation has an effect on the shape of the time series curve, but it does not improve the field compared to the measurements noticeably. The result that the assimilation changes the model, but without a clear improvement, could be due to different factors. This could happen if the simulated shape of the aerosol vertical profile differs from the measured one. Since we assimilate the column-integrated quantity, which does not contain the profile shape information, the model and measurements at a cer- 
Table 3. Correlation $(\rho)$, absolute bias $(\Delta)$ and root mean square error (RMSE) between AERONET observations and MOCAGE direct/assimilation run for the period of the TRAQA campaign between 25 June and 13 July 2012. Each of the stations in the table is identified by its site name, latitude/longitude, station height, number of observations and above-mentioned statistical parameters. AERONET site locations are also presented in Fig. 5.

\begin{tabular}{|c|c|c|c|c|c|c|c|c|}
\hline \multirow[b]{2}{*}{ Station (location) } & \multirow[b]{2}{*}{ Alt. (m) } & \multirow[b]{2}{*}{$\mathrm{N}_{\mathrm{obs}}$} & \multicolumn{3}{|c|}{ MOCAGE direct } & \multicolumn{3}{|c|}{ MOCAGE assimilation } \\
\hline & & & $\rho$ & $\Delta$ & RMSE & $\rho$ & $\Delta$ & RMSE \\
\hline Aubiere (FRA; $\left.45.8^{\circ} \mathrm{N}, 3.1^{\circ} \mathrm{E}\right)$ & 423 & 225 & 0.506 & 0.041 & 0.110 & 0.859 & 0.024 & 0.074 \\
\hline Autilla (ESP; $\left.42.0^{\circ} \mathrm{N}, 4.6^{\circ} \mathrm{W}\right)$ & 873 & 685 & 0.769 & 0.012 & 0.085 & 0.882 & 0.008 & 0.051 \\
\hline Avignon (FRA; $\left.43.9^{\circ} \mathrm{N}, 4.9^{\circ} \mathrm{E}\right)$ & 32 & 846 & 0.851 & 0.024 & 0.087 & 0.896 & 0.005 & 0.055 \\
\hline Barcelona $\left(\mathrm{ESP} ; 41.4^{\circ} \mathrm{N}, 2.1^{\circ} \mathrm{E}\right)$ & 125 & 378 & 0.802 & 0.110 & 0.169 & 0.900 & 0.038 & 0.084 \\
\hline Burjassot $\left(\mathrm{ESP} ; 39.5^{\circ} \mathrm{N}, 0.4^{\circ} \mathrm{W}\right)$ & 30 & 488 & 0.681 & 0.132 & 0.191 & 0.815 & 0.055 & 0.119 \\
\hline Cabo da Roca (PT; $\left.38.8^{\circ} \mathrm{N}, 9.5^{\circ} \mathrm{W}\right)$ & 140 & 77 & 0.965 & 0.130 & 0.263 & 0.939 & 0.032 & 0.120 \\
\hline Calern OCA (FRA; $\left.43.7^{\circ} \mathrm{N}, 6.9^{\circ} \mathrm{E}\right)$ & 1270 & 509 & 0.784 & 0.013 & 0.093 & 0.905 & 0.009 & 0.052 \\
\hline Carpentras (FRA; $\left.44.1^{\circ} \mathrm{N}, 5.1^{\circ} \mathrm{E}\right)$ & 100 & 738 & 0.774 & 0.023 & 0.085 & 0.876 & 0.005 & 0.055 \\
\hline Cerro Poyos (ESP; $\left.37.1^{\circ} \mathrm{N}, 3.5^{\circ} \mathrm{W}\right)$ & 1830 & 193 & 0.632 & 0.034 & 0.061 & 0.670 & 0.055 & 0.074 \\
\hline $\operatorname{Davos}\left(\mathrm{CH} ; 46.8^{\circ} \mathrm{N}, 9.8^{\circ} \mathrm{E}\right)$ & 1596 & 210 & 0.518 & 0.064 & 0.091 & 0.677 & 0.027 & 0.063 \\
\hline Ersa (FRA; $\left.43.0^{\circ} \mathrm{N}, 9.4^{\circ} \mathrm{E}\right)$ & 80 & 675 & 0.760 & 0.043 & 0.112 & 0.946 & 0.011 & 0.045 \\
\hline Evora $\left(\mathrm{PT} ; 38.6^{\circ} \mathrm{N}, 7.9^{\circ} \mathrm{W}\right)$ & 293 & 886 & 0.826 & 0.010 & 0.128 & 0.932 & 0.019 & 0.061 \\
\hline Frioul (FRA; $\left.43.3^{\circ} \mathrm{N}, 5.3^{\circ} \mathrm{E}\right)$ & 40 & 658 & 0.871 & 0.037 & 0.096 & 0.952 & 0.014 & 0.044 \\
\hline Granada (ESP; $\left.37.2^{\circ} \mathrm{N}, 3.6^{\circ} \mathrm{W}\right)$ & 680 & 883 & 0.677 & 0.041 & 0.129 & 0.930 & 0.003 & 0.057 \\
\hline Huelva $\left(\mathrm{ESP} ; 37.0^{\circ} \mathrm{N}, 6.6^{\circ} \mathrm{W}\right)$ & 25 & 1002 & 0.793 & 0.010 & 0.153 & 0.936 & 0.034 & 0.083 \\
\hline Laegeren $\left(\mathrm{CH} ; 47.5^{\circ} \mathrm{N}, 8.4^{\circ} \mathrm{E}\right)$ & 735 & 208 & 0.586 & 0.077 & 0.128 & 0.630 & 0.037 & 0.103 \\
\hline Lampedusa (ITA; $\left.35.5^{\circ} \mathrm{N}, 12.6^{\circ} \mathrm{E}\right)$ & 45 & 1058 & 0.573 & 0.084 & 0.124 & 0.845 & 0.006 & 0.061 \\
\hline Limassol (CYP; $\left.34.7^{\circ} \mathrm{N}, 33.0^{\circ} \mathrm{E}\right)$ & 22 & 978 & 0.338 & & 0.115 & 0.640 & 0.003 & 0.067 \\
\hline Madrid $\left(\mathrm{ESP} ; 40.5^{\circ} \mathrm{N}, 3.7^{\circ} \mathrm{W}\right)$ & 680 & 904 & 0.731 & 0.011 & 0.097 & 0.878 & 0.004 & 0.058 \\
\hline Malaga (ESP; $\left.36.7^{\circ} \mathrm{N}, 4.5^{\circ} \mathrm{W}\right)$ & 40 & & 0.702 & & & 0.910 & 0.047 & 0.088 \\
\hline Messina $\left(\right.$ ITA; $\left.38.2^{\circ} \mathrm{N}, 15.6^{\circ} \mathrm{E}\right)$ & 15 & 573 & 0.519 & 0.068 & 0.111 & 0.835 & 0.020 & 0.060 \\
\hline Montsec $\left(\mathrm{ESP} ; 42.1^{\circ} \mathrm{N}, 0.7^{\circ} \mathrm{E}\right)$ & 1574 & & 0.662 & & & 0.892 & 0.009 & 0.044 \\
\hline Nes Ziona (ISR; $\left.31.9^{\circ} \mathrm{N}, 34.8^{\circ} \mathrm{E}\right)$ & 40 & 593 & 0.266 & 0.053 & 0.111 & 0.788 & 0.014 & 0.063 \\
\hline OHP Observatoire (FRA; $\left.43.9^{\circ} \mathrm{N}, 5.7^{\circ} \mathrm{E}\right)$ & 680 & 657 & 0.742 & 0.019 & 0.089 & 0.886 & 0.000 & 0.053 \\
\hline Oujda (MAR; $\left.34.7^{\circ} \mathrm{N}, 1.9^{\circ} \mathrm{W}\right)$ & 620 & 330 & 0.459 & 0.202 & 0.221 & 0.756 & 0.090 & 0.116 \\
\hline Palencia $\left(\mathrm{ESP} ; 42.0^{\circ} \mathrm{N}, 4.5^{\circ} \mathrm{W}\right)$ & 750 & 649 & 0.859 & 0.030 & 0.104 & 0.919 & 0.002 & 0.051 \\
\hline Palma de Mallorca (ESP; $\left.39.6^{\circ} \mathrm{N}, 2.6^{\circ} \mathrm{E}\right)$ & 10 & 797 & 0.754 & 0.129 & 0.163 & 0.888 & 0.048 & 0.084 \\
\hline Porquerolles (FRA; $\left.43.0^{\circ} \mathrm{N}, 6.2^{\circ} \mathrm{E}\right)$ & 22 & 637 & 0.805 & 0.005 & 0.071 & 0.923 & 0.020 & 0.044 \\
\hline Sagres $\left(\mathrm{PT} ; 37.0^{\circ} \mathrm{N}, 8.9^{\circ} \mathrm{W}\right)$ & 26 & 405 & 0.901 & 0.017 & 0.197 & 0.958 & 0.023 & 0.088 \\
\hline Sede Boker (ISR; $30.9^{\circ} \mathrm{N}, 34.8^{\circ} \mathrm{E}$ ) & 480 & 950 & 0.240 & 0.009 & 0.080 & 0.552 & 0.065 & 0.095 \\
\hline San Giuliano (FRA; $\left.42.3^{\circ} \mathrm{N}, 9.5^{\circ} \mathrm{E}\right)$ & 10 & 768 & 0.675 & 0.084 & 0.137 & 0.908 & 0.066 & 0.089 \\
\hline Tabernas $\left(\mathrm{ESP} ; 37.1^{\circ} \mathrm{N}, 2.4^{\circ} \mathrm{W}\right)$ & 500 & 740 & 0.754 & 0.129 & 0.184 & 0.927 & 0.038 & 0.078 \\
\hline Tizi Ouzou (DZA; $\left.36.7^{\circ} \mathrm{N}, 4.1^{\circ} \mathrm{E}\right)$ & 133 & 241 & 0.686 & 0.195 & 0.203 & 0.764 & 0.079 & 0.095 \\
\hline Villefranche $\left(\mathrm{FRA} ; 43.7^{\circ} \mathrm{N}, 7.3^{\circ} \mathrm{E}\right)$ & 130 & 480 & 0.707 & 0.064 & 0.113 & 0.873 & 0.033 & 0.067 \\
\hline Zaragoza $\left(\mathrm{ESP} ; 41.6^{\circ} \mathrm{N}, 0.9^{\circ} \mathrm{W}\right)$ & 250 & 916 & 0.722 & 0.053 & 0.100 & 0.816 & 0.040 & 0.073 \\
\hline All sites & 29840 & 0.740 & 0.050 & 0.115 & 0.883 & 0.006 & 0.070 & \\
\hline
\end{tabular}

tain height will not match if the modelled profile shape is far from the real one, although the AOD values could match well. A similar impact could arise if the modelled mixture of aerosol types and the size distribution are different from the real one. The difference in the sizes would be easily noticeable in the aerosol number concentration, even if the modelled and observed AOD values correspond well. The third factor that could contribute to the difference between the modelled and the assimilated curve is a possible declining effect with time of previous assimilation cycles on the assimilated curve.
During flight $\mathrm{C}$ (Fig. 8c), the aircraft flew directly through the desert dust plume. The concentrations are elevated over a wide range of heights. The assimilation model run significantly improves the aerosol number concentration, by having it close to the measured ones for most of the flight path within the plume. If satellite measurements are accurate, concentrations at one height after an assimilation cycle can only closely correspond to measured ones if the shape of the vertical profile is well simulated in the direct model run. To further explore this, in the following subsection we compare the modelled and the measured vertical profiles. 

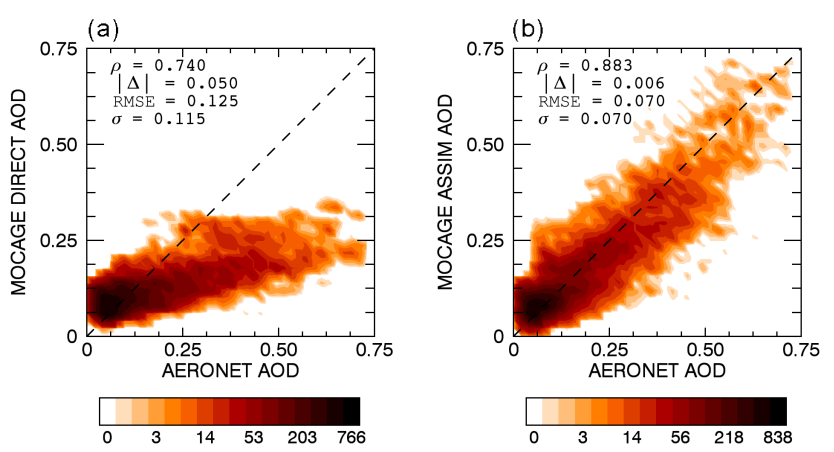

Figure 7. Scatter plots of aerosol optical depths (where colours represent the number of points) from the independent observation dataset (AERONET) and the simulations: the direct model run (a) and the assimilation model run (b). In each panel, correlation $(\rho)$, absolute bias $(\Delta)$, root mean square error (RMSE) and standard deviation $(\sigma)$ are noted. The included data correspond to the period of the TRAQA campaign from 25 June until 13 July 2012, and covers all stations presented in Fig. 5.

\subsection{In situ balloon concentration measurements}

During TRAQA, LOAC flew on three balloons, all launched from Martigues, near Marseille (FRA). Two flights on 29 June 2012, and one on 6 July 2012, are presented in Fig. 9. The first two flights flew through the desert dust plume. The path of the second LOAC flight is near the path of the aircraft flight $\mathrm{C}$ (Fig. 8c), which allows us to directly compare the two measurements. The total horizontal motion of LOAC is fairly small $\leq 15 \mathrm{~km}$. Therefore, we will assume that LOAC measurements represent the aerosol vertical profile above the launch place.

The first two flights (Fig. 9a and b) are launched at two different times of the same day, in the morning and at noon, but they flew through the same desert dust plume. In both cases, the assimilation model run matches the measurements very closely. It simulates both the shape of the profile and the aerosol number concentration well. The direct model run simulates the shape of the vertical profile well, but it underestimates the aerosol concentration in the plume that the assimilation corrects. For the second flight, although the concentrations in the plume are clearly improved, near the surface, the increase of aerosols led to a larger overestimation in the model. Sometimes, the generalized multiplicative change of the aerosol profile in the assimilation can produce unsatisfactory effects in some layers.

LOAC measurements acquired during the balloon flight (Fig. 9b) are co-located with the aircraft measurements (Fig. 8c). They match with the assimilation model run profile well, which confirms the interpretation already discussed: the aerosol concentration after an assimilation cycle at a certain height can only be correct if the profile shape is well simulated in the direct model run.
The third LOAC flight (Fig. 9c) measured moderate aerosol concentrations coinciding with an air pollution episode. The assimilation model run matches well with the measured concentrations. The direct model run underestimates the concentrations only in lower levels. However, when compared with the assimilation model run, the assimilation changes the aerosol vertical profile significantly: the concentrations are increased much more in the lower levels, while in higher levels the change is less important. In this case, the different shape of the profile in the direct model run and the assimilation model run is a result of the continuous multi-day assimilation of AOD over many assimilation cycles, and the mixing of the aerosols coming from different levels and regions where they were already assimilated (or not) in previous assimilation cycles. Different directions of the origin for air parcel at different heights shown in Fig. 9d confirm this assumption. This demonstrates that the continuous assimilation of good-quality AOD observations and/or model propagation of the increment can correct a shape of the aerosol vertical profile, although a single AOD assimilation cycle can only expand or shrink the profile shape (as the AOD observations do not contain the information on the vertical). For the profile in Fig. 9c, by comparing the forecast and the analysis of the same assimilation window, we see that the single AOD assimilation cycle expands the profile but does not change its shape, something that multiple cycles and the model propagation of the increment do. Fig. 9d shows the back trajectories of air parcels at different heights at the location corresponding to Fig. 9c, and confirms that the aerosols on different levels come from different directions and regions where they have been already assimilated in previous cycles.

\subsection{The profile evolution}

The profile evolution in the continuous multi-day assimilation run is further explored in Fig. 10. We follow the desert dust plume over the course of 1 week from 25 June to 2 July 2012 from its sources in Africa to its weakening and dissolution in the Mediterranean Sea (Fig. 10c). The aerosols at the different layers are carried by the winds at different velocities and directions, and, as particles, they undergo different physical processes (e.g. dry and wet deposition, sedimentation). Therefore, we cannot follow the dust plume by following an air parcel. Instead, to track the plume we use a criterion based on the high values of AOD. The plume, after its emission, heads west and passes over a couple of other dust sources. Near the Canary Islands the plume turns north-east towards the Mediterranean basin under the influence of a low-pressure system centred near the British Isles. MODIS directly observes the plume each day during the considered period (MODIS passes are marked by triangles in Fig. 10b), and these observations in the assimilation model run have a considerable impact on the plume. When comparing the direct model run (Fig. 10a) and the assimilation 
(a)

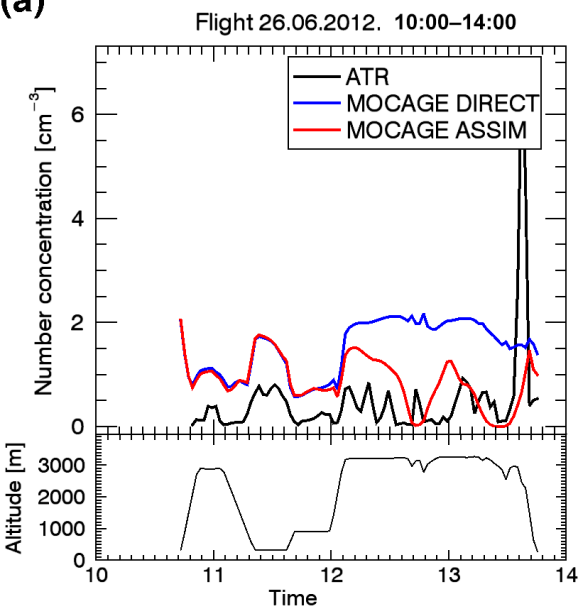

(c)

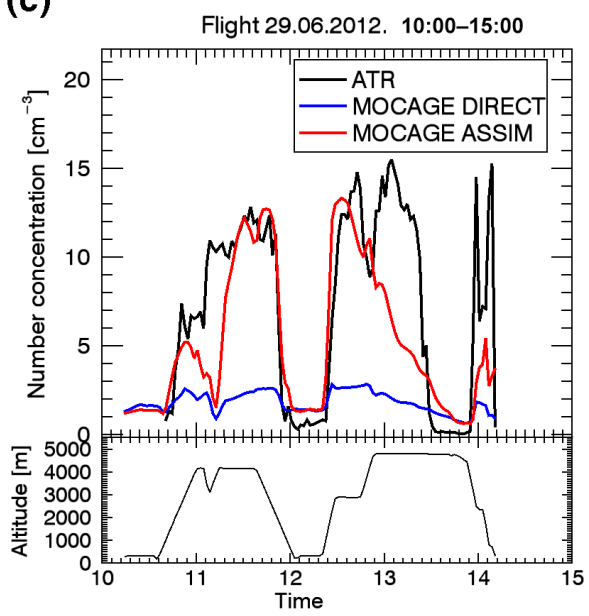

(b)

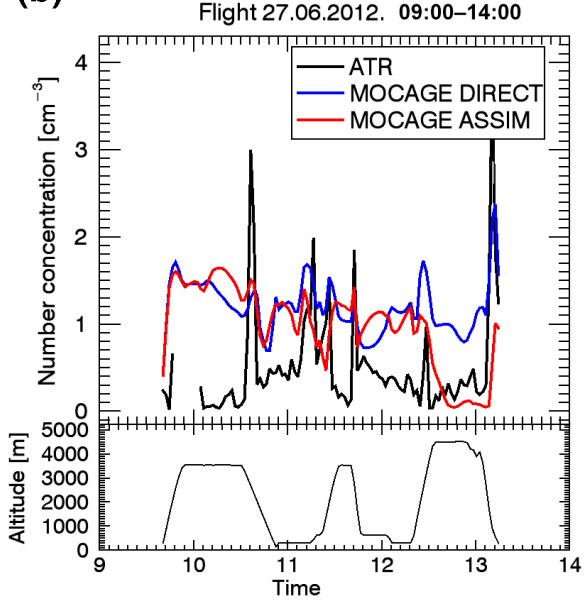

(d)
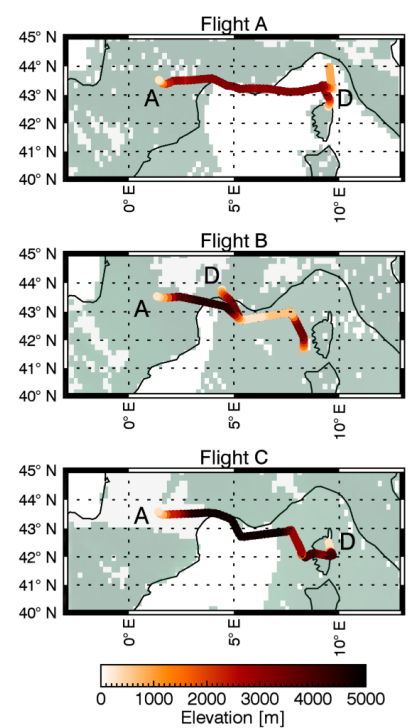

Figure 8. Aerosol number concentration $\left(\mathrm{cm}^{-3}\right)$ from the PCASP instrument on board the ATR aircraft (black line) compared with the direct model run (blue line) and the assimilation model run (red line) for three different flights: flight A on 26 June 2012 (a), flight B on 27 June 2012 (b) and flight C on 29 June 2012 (c). The altitude of the aircraft is also given for all three flights. In addition, the maps of flight tracks are presented (d) with the points of departure (D) and arrival (A) for each flight, and the positions of the assimilated observations during the day of flight (dark green). The colours of the tracks represent the altitude of the aircraft during the flight, with values defined in the colour bar. The aerosols are considered in the size range from 1 to $2.5 \mu \mathrm{m}$.

model run (Fig. 10b), the most obvious assimilation impact is the change of the intensity of the plume in the first part of the trajectory. However, the profile shape also evolves considerably: at different moments the plume maxima are shifting their peak heights, and the different layers are changing their relative densities. The change of the profile shape is visible on a large part of the plume trajectory, which means that this can be an important feature of a multi-day AOD assimilation.

There are different effects that the assimilation can have on the profile shape. While following the plume based on the AOD values, different air masses enter and exit our trajectory based on their different transport velocities and directions. Thus, aerosols that are assimilated at different places later can be gathered in one vertical profile. Then, the continuous multicycle assimilation can additionally amplify or reduce these differences in a profile. In Fig. 10a and b, the change of the profile shape is noticeable on 28 and 29 June when the plume is near the coast of Morocco. The assimilation increases aerosol mixing ratios in lower layers, and decreases them in higher layers. We see a similar effect around 1 July in the northern part of the basin, where the profile shape changes due to the altitude varying wind direction and velocity and thus the associated pronounced air mass mixing. 
(a)

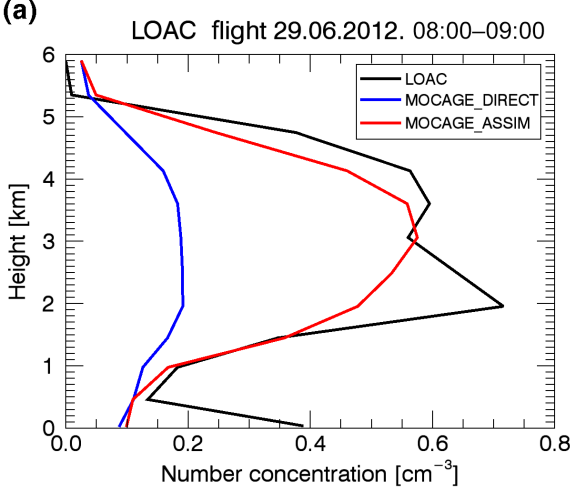

(c)

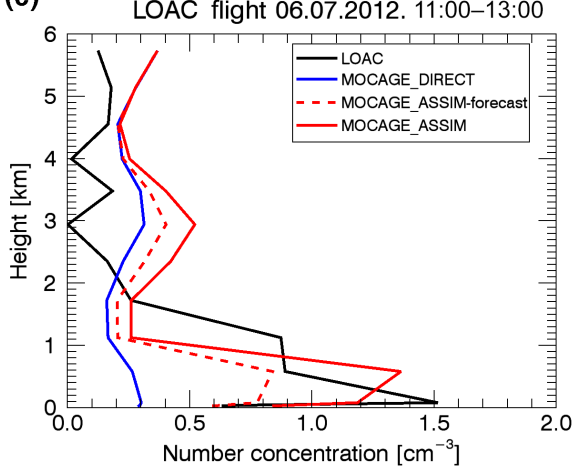

(b)

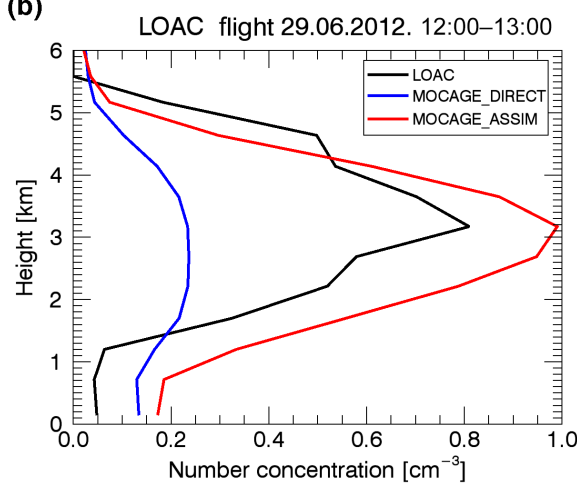

(d)
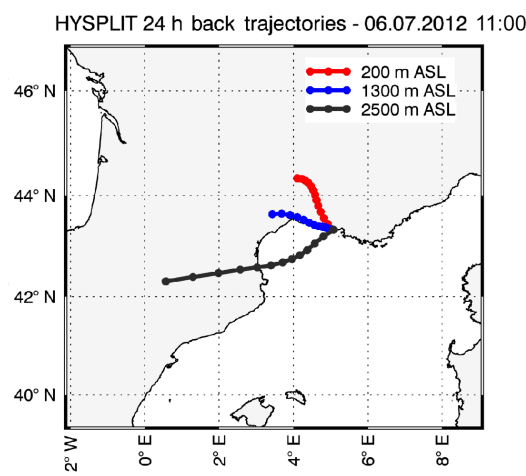

Figure 9. Aerosol number concentration $\left(\mathrm{cm}^{-3}\right)$ from the LOAC instrument on board the meteorological sounding balloons. The presented flights are performed: in the morning of 29 June 2012 (a), at noon of 29 June 2012 (b) and on 6 July 2012 (c). LOAC measurements (black line) are compared with the direct model run (blue line) and the assimilation model run (red line). For the third flight, we also present the $1 \mathrm{~h}$ forecast (first guess) started from the assimilated conditions of $1 \mathrm{~h}$ before (dashed red line). The aerosols are considered in the size range from 2.5 to $100 \mu \mathrm{m}$. In addition, for the third flight, we present the $12 \mathrm{~h}$ back trajectories obtained by the National Oceanic and Atmospheric Administration's HYSPLIT model (d). They show directions of the origin of air parcels at the three different starting heights, 200, 1300 and $2500 \mathrm{~m}$ above sea level, for the starting location of $42.33^{\circ} \mathrm{N}, 5.08^{\circ} \mathrm{E}$ and the starting time of 6 July 2012 at 11:00 UTC.

\section{Discussion}

Results presented in this paper show that the AOD data assimilation is an efficient technique to improve modelled aerosol fields. Assimilated fields have better statistical performances than the direct model run in comparison with the assimilated observations, and with independent AOD observations and in situ measurements. The uncertainties in the direct model in the case of a desert dust outbreak come primarily from the uncertainties in the desert dust emissions. The dust emission into the atmosphere is a threshold process, which is very sensitive to uncertainties in the wind field. The small changes in wind can produce significant differences in the emitted quantities. The AOD assimilation proved to be a technique capable of reducing the effects of such uncertainties in the modelled aerosol fields.

In doing so, our assimilation system showed to be more efficient in lowering overestimated AOD values in the model than increasing underestimated values. This can be seen in Fig. 1, and it is directly related to how matrices $\mathbf{B}$ and $\mathbf{R}$ are defined in the experiment. By defining variances as the percentage of modelled and observed quantities, and making this factor 2 times smaller for observations, we penalized the high AOD values in the model. This directly affects the analyses, and is later reflected in the forecasts.

To regulate this feature, one of the possible and the simplest (ad hoc) approaches would be to limit the observation error in the matrix $\mathbf{R}$ up to a fixed value, which would give more weight to observations in the case of high observed AOD. This would have a partial effect, only influencing observations above a certain AOD, and in the case of the substantial underestimation in the model, it would have a limited impact. Another approach would be to try to define the matrix $\mathbf{B}$ differently. Previous studies show that a rigorously defined matrix $\mathbf{B}$ can slightly improve the analysis quality (Kahnert, 2011; Massart et al., 2012). In MOCAGEValentina, in the framework of the MACC (Monitoring Atmospheric Composition and Climate) project, the influence of different matrices $\mathbf{B}$ was assessed for the case of ozone assimilation (Jaumouillé et al., 2012). One of the approaches was the percentage method used in our experiment. The second approach was the monthly a posteriori diagnostics 
(a)

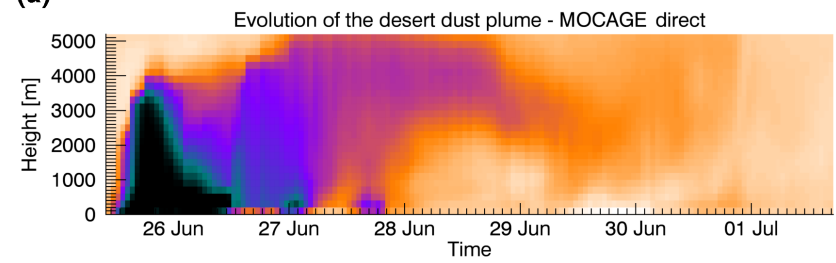

(b)

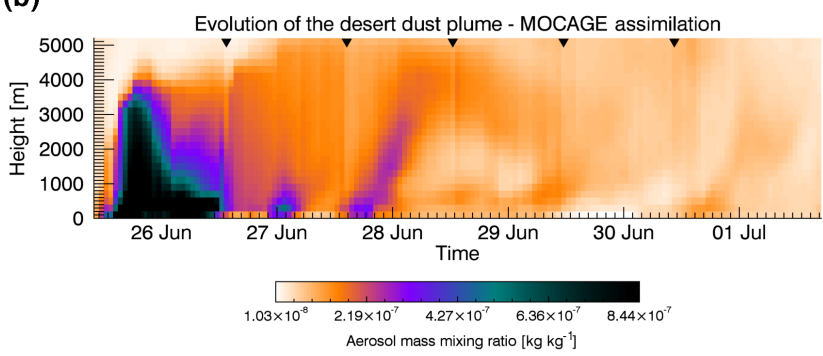

(c)

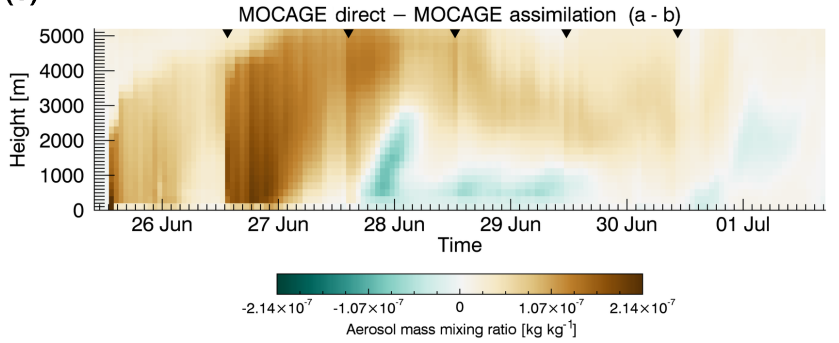

(d)

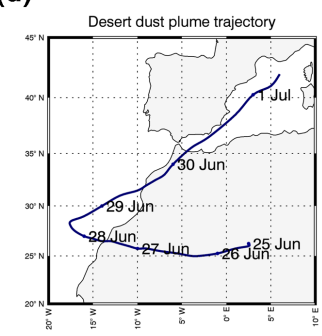

Figure 10. The evolution of the aerosol vertical profile over the course of 1 week from 25 June to 2 July 2012 in the direct model run (a) and the assimilation model run (b) and the difference between the direct and the assimilated model run (c). The units are in mass mixing ratios, with the values represented by colours identified in colour bars. In (b) the passes of the MODIS over the plume are marked by the triangles. The desert dust plume is followed from its sources in Africa to its weakening and dissolution in the Mediterranean Sea (d).

(Desroziers et al., 2005) computed from the data of a month before, and it is adapted for operational purposes since the data from the past are readily available. The third approach is to calculate diagnostics from an ensemble of runs with perturbed emissions with homogeneous or heterogeneous correlation length scales. The main conclusion is that all methods significantly improve the modelled field, and that relative differences between different methods are small compared to the rate of improvement by assimilation. For aerosols, the transport processes are more important than for ozone, but the work of Jaumouillé et al. (2012) could give an idea of what to expect in the model from redefining the construction of the matrices $\mathbf{B}$ and $\mathbf{R}$. Moreover, it should be kept in mind that using a dense observation field, like our MODIS superobservation field, limits the effects of the spatial diffusion of the increment. This makes the covariances of the matrix $\mathbf{B}$ less important than in the case of sparse observations.

In our system, the lack of secondary aerosols is presumed to have an influence on assimilation performance. This could lead to an underestimation of the direct model AOD in the regions where the secondary aerosols have an important influence. During the TRAQA period, the primary aerosols had a dominant effect on the aerosol field, mainly because of the two desert dust events that occurred during the campaign, and this was favourable for the evaluation of our system. In the direct model, differences between the model and the observations appear because of different model uncertainties, including simplified and neglected processes. However, the differences do not have a constant or cumulative nature; the model sometimes overestimates or underestimates AOD. To take into account these uncertainties in the assimilation process, we defined the variances in the matrix $\mathbf{B}$ in such a way that it allows a margin for the background errors (Talagrand, 2003): the percentage for the background errors is twice as large as for the observation errors. The developments of an inorganic secondary aerosol module in MOCAGE are carried in parallel with the developments on the AOD assimilation system (Guth et al., 2015). This has a beneficial effect in the model and consequently, is expected to improve the analysis after its inclusion in the assimilation module. To take into account the model uncertainties, there are also other possibilities. One would be to add an additional term in the cost function where we would describe the errors of the model evolution (Tréemolet, 2006). This method can be used in the 4-D-Var systems and, besides the implementation of the 4-DVar method, it demands additional computational resources 
in assimilation. In addition, it is difficult to define the model error covariance matrix in it. Another possibility would be to apply techniques of bias correction (e.g. Dee and Uppala, 2008).

The impact of the AOD assimilation on the model found in our study is coherent with findings of other studies (Zhang et al., 2008; Schutgens et al., 2010; Liu et al., 2011). Our approach is the most similar to the approach used by Benedetti et al. (2009). We choose the same control variable, and the choice of the control variable is essential when the model prognostic and the observed quantities differ as in the case of AOD. The differences in our systems are the number of bins to which the increment is repartitioned (11 bins for five species in Benedetti et al., 2009 and 24 bins for four species in our system) and the assimilation method (4-DVAR against 3-D-FGAT). Benedetti et al. (2009) derived the matrix B using the NMC (National Meteorological Center) method (Parrish and Derber, 1992). Satellite AOD errors are defined for retrievals over water using a multi-regression formula, and for retrievals over land using the percentage approach with defining a minimal possible error. Their 4-D-Var analysis results qualitatively showed a very similar impact of assimilation as in this study.

We assimilated the data of MODIS, which has two overpasses per day during daytime. Satellite data with higher temporal resolution exist. SEVIRI data with a temporal resolution of $15 \mathrm{~min}$ were used as independent data to evaluate the results. Assimilating such data could further improve the agreement between observations and the assimilation model run, but considering the moderate temporal variability of AOD fields, we would not expect a substantial improvement. In addition, the SEVIRI AOD products are less accurate compared to MODIS. The TRAQA period used in our experiment is in northern summer with a good likelihood of having a cloud-free field, and two overpasses per day were able to cover a significant part of the control domain each day. Possibly, a higher temporal resolution of data for assimilation could have a stronger effect on the model, especially during the winter-time.

\section{Summary and conclusion}

In this study we present the development and validation of the MOCAGE-Valentina system for assimilating aerosol optical depth (AOD). Our system assimilates aerosol optical depth with the 3-D-FGAT method, and uses the total 3-D aerosol concentration as a control variable. We examine how 2-D AOD observations in a continuous multicycle assimilation can improve the model aerosol representation, including the vertical aerosol profile. We use accurate in situ aircraft and balloon measurements plus other remotely sensed data to provide independent validation of the impact of the assimilation. The MODIS L2 data are assimilated with a model resolution of about $0.2^{\circ}$ and a $1 \mathrm{~h}$ assimilation cycle over the region covering northern Africa, the Mediterranean basin and southern Europe for the period of the TRAQA campaign in the northern summer of 2012.

The assimilated model fields show greatly improved aerosol representation compared to the independently observed datasets, including the 3-D distributions. The comparison with SEVIRI and AERONET AOD observations, as independent datasets, confirms the significant positive effect of the AOD assimilation to the model. For example, the comparison with AERONET data shows that the assimilation decreased the bias in AOD (from 0.050 to 0.006 ) and increased the correlation (from 0.74 to 0.88 ).

The TRAQA campaign provided independent 3-D data on aerosol concentration. The assimilation sometimes improved the modelled fields and sometimes had little effect. The best results as expected occurred when the shape of the vertical profile was correctly simulated by the direct (unassimilated) model. The shape of the aerosol vertical profiles does not change during one assimilation cycle because AOD observations do not contain any vertical information, but the profile shape can change and be improved by the AOD assimilation because different parts of the column can be carried by winds from different directions. The AOD assimilation can also impact aerosol size and type for the same reason, but this was not evident in this experiment. The AOD assimilation proved to be a very efficient technique to improve the model forecast of bulk aerosols and a powerful tool for producing reanalyses or studying past events.

As of an outlook of further developments, the next steps will consist of improving the system performance and broadening its capabilities. For example, it could be advantageous to assimilate observations from different instruments at the same time. The aerosol observations from space are available from various instruments located on different satellites, which can provide different spatial and temporal coverage and resolutions. Combining complementary data from different instruments could improve the system performance, but the possible inter-instrument biases would need to be carefully considered.

In addition, the same or even bigger positive effect of the assimilation could be expected in the case of other strong aerosol events, like biomass burning or a volcanic ash plume, where the model emission uncertainties are often even larger than in the case of desert dust plumes.

By assimilating AOD observations at several wavelengths, we can get information on aerosol size. If aerosol absorption can be measured, then we can discriminate between carbonaceous and other aerosols. Then, with this information we could modify the size distribution in the model. To achieve this in the system, it would be necessary to study the relationship and sensitivity between the size and bin distribution in MOCAGE and the aerosol Ångstrom exponent obtained from multi-wavelength measurements.

If we want to introduce direct information of the vertical profile from observations into the model, we would need to 
assimilate another type of observations. Lidar observations, ground- or space-based, are an obvious choice. The control variable defined as the 3-D total concentration is also well adapted for the assimilation of lidar profiles. This facilitates the implementation of the lidar assimilation into the system, and in the longer term also makes feasible a simultaneous assimilation of the AOD and lidar profiles as possibly complimentary datasets.

\section{Data availability}

The MOCAGE, PCASP and LOAC TRAQA data are available on the ChArMEx database at http://mistrals.sedoo.fr/ChArMEx/ with subsequent DOI: the MOCAGE direct run data (doi:10.14768/MISTRALSCHARMEX.1034) (El Amraoui and Sič, 2013), the MOCAGE assimilation run data (doi:10.14768/MISTRALSCHARMEX.1449) (El Amraoui and Sič, 2016), the PCASP TRAQA data (doi:10.6096/MISTRALS-ChArMEx.998) (Piguet and Perrin, 2013) and the LOAC TRAQA data (doi:10.6096/MISTRALS-ChArMEx.833) (Renard, 2012). The user must register before having access to the data. The MODIS/Aqua and MODIS/Terra Atmosphere L2 Aerosol Products (MYD04-C51 and MOD04-C51) were acquired from the Level-1 \& Atmosphere Archive and Distribution System (LAADS) Distributed Active Archive Center (DAAC, http://ladsweb.nascom.nasa.gov) (Hsu et al., 2008). The SEVIRI/MSG product (SEV_AER-OC) was acquired from the ICARE data centre (http://www.icare.univ-lille1.fr) (Thieuleux et al., 2005a). The user must register before having access to the data. The AERONET level 2 data were acquired from the AERONET network website (http://aeronet.gsfc.nasa.gov/) (Holben et al., 2012).

Acknowledgements. This work has been funded by Centre National de Recherches Météorologiques (CNRM-GAME) of Météo-France and Centre National de la Recherche Scientifique (CNRS). The authors would like to thank Jean-Luc Attié, the TRAQA principal investigator, and all TRAQA/ChArMEx collaborators for producing and providing the data used in this study. TRAQA was funded by ADEME/PRIMEQUAL and MISTRALS/ChArMEx programmes and Observatoire Midi-Pyrénées. We acknowledge the AERONET principal investigators and their staff for establishing and maintaining the sites used in this investigation. We also acknowledge the Global Fire Emission Database project and Lamarque et al. (2010) for the biomass burning and carbonaceous aerosol emissions, the MODIS mission team and scientists for the production of the MODIS data, as well as Thieuleux et al. (2005b) and the ICARE data centre for developing and producing the SEVIRI-retrieved aerosol data that we used in this study.

Edited by: W. Lahoz

Reviewed by: three anonymous referees

\section{References}

Andersson, E., Haseler, J., Undén, P., Courtier, P., Kelly, G., Vasiljevic, D., Brankovic, C., Gaffard, C., Hollingsworth, A., Jakob, C., Janssen, P., Klinker, E., Lanzinger, A., Miller, M., Rabier, F., Simmons, A., Strauss, B., Viterbo, P., Cardinali, C., and Thépaut, J.-N.: The ECMWF implementation of three-dimensional variational assimilation (3D-Var). III: Experimental results, Q. J. Roy. Meteor. Soc., 124, 1831-1860, doi:10.1002/qj.49712455004, 1998.

Attié, J.-L. et al.: Transport of Pollution and Air Quality experiment over the Mediterranean basin (TRAQA/ChArMEx campaign), in preparation, 2016.

Bechtold, P., Bazile, E., Guichard, F., Mascart, P., and Richard, E.: A mass-flux convection scheme for regional and global models, Q. J. Roy. Meteor. Soc., 127, 869-886, 2001.

Benedetti, A., Morcrette, J.-J., Boucher, O., Dethof, A., Engelen, R. J., Fisher, M., Flentje, H., Huneeus, N., Jones, L., Kaiser, J. W., Kinne, S., Mangold, A., Razinger, M., Simmons, A. J., and Suttie, M.: Aerosol analysis and forecast in the European centre for medium-range weather forecasts integrated forecast system: 2. Data assimilation, J. Geophys. Res.-Atmos., 114, D13205, doi:10.1029/2008JD011115, 2009.

Boucher, O., Randall, D., Artaxo, P., Bretherton, C., Feingold, G., Forster, P., Kerminen, V.-M., Kondo, Y., Liao, H., Lohmann, U., Rasch, P., Satheesh, S. K., Sherwood, S., Stevens, B., and Zhang, X. Y.: Clouds and aerosols, in: Climate change 2013: The physical science basis: Working Group I Contribution to the Fifth Assessment Report of the Intergovernmental Panel on Climate Change, Cambridge University Press, Cambridge and New York, 571-657, 2013.

Breon, F.-M., Vermeulen, A., and Descloitres, J.: An evaluation of satellite aerosol products against sunphotometer measurements, Remote Sens. Environ., 115, 3102-3111, 2011.

Buis, S., Piacentini, A., and Déclat, D.: PALM: a computational framework for assembling high-performance computing applications, Concurr. Comp.-Pract. E., 18, 231-245, 2006.

Cai, Y., Snider, J. R., and Wechsler, P.: Calibration of the passive cavity aerosol spectrometer probe for airborne determination of the size distribution, Atmos. Meas. Tech., 6, 2349-2358, doi:10.5194/amt-6-2349-2013, 2013

Collins, W. D., Rasch, P. J., Eaton, B. E., Khattatov, B. V., Lamarque, J.-F., and Zender, C. S.: Simulating aerosols using a chemical transport model with assimilation of satellite aerosol retrievals: Methodology for INDOEX, J. Geophys. Res.-Atmos., 106, 7313-7336, doi:10.1029/2000JD900507, 2001.

Courtier, P., Thépaut, J.-N., and Hollingsworth, A.: A strategy for operational implementation of 4D-Var, using an incremental approach, Q. J. Roy. Meteor. Soc., 120, 1367-1387, 1994.

Dai, T., Schutgens, N. A., Goto, D., Shi, G., and Nakajima, T.: Improvement of aerosol optical properties modeling over Eastern Asia with MODIS AOD assimilation in a global non-hydrostatic icosahedral aerosol transport model, Environ. Pollut., 195, 319329, doi:10.1016/j.envpol.2014.06.021, 2014.

Daley, R.: Atmospheric data analysis, No. 2, Atmospheric and Space Science Series, Cambridge University Press, 1993.

De Leeuw, G., Kinne, S., Léon, J.-F., Pelon, J., Rosenfeld, D., Schaap, M., Veefkind, P. J., Veihelmann, B., Winker, D. M., and von Hoyningen-Huene, W.: Retrieval of aerosol properties, 
in: The remote sensing of tropospheric composition from space, Springer, 259-313, 2011.

Dee, D. and Uppala, S.: Variational bias correction in ERA-Interim, ECMWF, 2008.

Desroziers, G., Berre, L., Chapnik, B., and Poli, P.: Diagnosis of observation, background and analysis-error statistics in observation space, Q. J. Roy. Meteor. Soc., 131, 3385-3396, 2005.

Dufour, A., Amodei, M., Ancellet, G., and Peuch, V.-H.: Observed and modelled "chemical weather" during ESCOMPTE, Atmos. Res., 74, 161-189, 2005.

El Amraoui, L. and Sič, B.: MOCAGE direct aerosol run data for the period of the TRAQA campaign, ChArMEx database, available at: http://mistrals.sedoo.fr/ChArMEx/ (registration required, last access: November 2016), doi:10.14768/MISTRALSCHARMEX.1034, 2013.

El Amraoui, L. and Sič, B.: MOCAGE assimilation aerosol run data for the period of the TRAQA campaign, ChArMEx database, available at: http://mistrals.sedoo.fr/ChArMEx/ (registration required, last access: November 2016), doi:10.14768/MISTRALSCHARMEX.1449, 2016.

Elbern, H., Schmidt, H., and Ebel, A.: Variational data assimilation for tropospheric chemistry modeling, J. Geophys. Res.-Atmos., 102, 15967-15985, doi:10.1029/97JD01213, 1997.

Fisher, M. and Andersson, E.: Developments in 4D-Var and Kalman filtering, European Centre for Medium-Range Weather Forecasts, Reading, UK, 2001.

Fisher, M. and Lary, D. J.: Lagrangian four-dimensional variational data assimilation of chemical species, Q. J. Roy. Meteor. Soc., 121, 1681-1704, doi:10.1002/qj.49712152709, 1995.

Fuzzi, S., Andreae, M. O., Huebert, B. J., Kulmala, M., Bond, T. C., Boy, M., Doherty, S. J., Guenther, A., Kanakidou, M., Kawamura, K., Kerminen, V.-M., Lohmann, U., Russell, L. M., and Pöschl, U.: Critical assessment of the current state of scientific knowledge, terminology, and research needs concerning the role of organic aerosols in the atmosphere, climate, and global change, Atmos. Chem. Phys., 6, 2017-2038, doi:10.5194/acp-62017-2006, 2006.

Giorgi, F. and Chameides, W. L.: Rainout lifetimes of highly soluble aerosols and gases as inferred from simulations with a general circulation model, J. Geophys. Res.-Atmos., 91, 14367-14376, 1986.

Guth, J., Josse, B., Marécal, V., Joly, M., and Hamer, P.: First implementation of secondary inorganic aerosols in the MOCAGE version R2.15.0 chemistry transport model, Geosci. Model Dev., 9, 137-160, doi:10.5194/gmd-9-137-2016, 2016.

Hess, M., Koepke, P., and Schult, I.: Optical Properties of Aerosols and Clouds: The Software Package OPAC, B. Am. Meteorol. Soc., 79, 831-844, doi:10.1175/15200477(1998)079<0831:OPOAAC>2.0.CO;2, 1998.

Holben, B., Eck, T., Slutsker, I., Tanré, D., Buis, J., Setzer, A., Vermote, E., Reagan, J., Kaufman, Y., Nakajima, T., Lavenu, F., Jankowiak, I., and Smirnov, A.: AERONET - A federated instrument network and data archive for aerosol characterization, Remote Sens. Environ., 66, 1-16, doi:10.1016/S00344257(98)00031-5, 1998.

Holben, B., Eck, T., Slutsker, I., Tanré, D., Buis, J., Setzer, A., Vermote, E., Reagan, J., Kaufman, Y., Nakajima, T., Lavenu, F., Jankowiak, I., and Smirnov, A.: AERONET Aerosol Optical Depth Level 2.0 Data, AERONET, Goddard Space Flight Center, available at: http://aeronet.gsfc.nasa.gov/ (last access: November 2016), 2012.

Hsu, N. C., Tsay, S.-C., King, M. D., and Herman, J. R.: Deep Blue retrievals of Asian aerosol properties during ACE-Asia, IEEE T. Geosci. Remote, 44, 3180-3195, 2006.

Hsu, C., Remer, L., Mattoo, S., and Chu, A.: MODIS Atmosphere L2 Aerosol Product - Collection 051. NASA MODIS Adaptive Processing System, Goddard Space Flight Center, available at: http://ladsweb.nascom.nasa.gov (last access: November 2016), 2008.

Jaeglé, L., Quinn, P. K., Bates, T. S., Alexander, B., and Lin, J.-T.: Global distribution of sea salt aerosols: new constraints from in situ and remote sensing observations, Atmos. Chem. Phys., 11, 3137-3157, doi:10.5194/acp-11-3137-2011, 2011.

Jaumouillé, E., Massart, S., Piacentini, A., Cariolle, D., and Peuch, V.-H.: Impact of a time-dependent background error covariance matrix on air quality analysis, Geosci. Model Dev., 5, 10751090, doi:10.5194/gmd-5-1075-2012, 2012.

Josse, B., Simon, P., and Peuch, V.-H.: Radon global simulations with the multiscale chemistry and transport model MOCAGE Tellus B, 56, 339-356, 2004.

Kahnert, M.: Variational data analysis of aerosol species in a regional CTM: background error covariance constraint and aerosol optical observation operators, Tellus B, 60, 5, 753-770, doi:10.1111/j.1600-0889.2008.00377.x, 2011.

Kaiser, J. W., Heil, A., Andreae, M. O., Benedetti, A., Chubarova, N., Jones, L., Morcrette, J.-J., Razinger, M., Schultz, M. G., Suttie, M., and van der Werf, G. R.: Biomass burning emissions estimated with a global fire assimilation system based on observed fire radiative power, Biogeosciences, 9, 527-554, doi:10.5194/bg-9-527-2012, 2012.

Kanakidou, M., Seinfeld, J. H., Pandis, S. N., Barnes, I., Dentener, F. J., Facchini, M. C., Van Dingenen, R., Ervens, B., Nenes, A., Nielsen, C. J., Swietlicki, E., Putaud, J. P., Balkanski, Y., Fuzzi, S., Horth, J., Moortgat, G. K., Winterhalter, R., Myhre, C. E. L., Tsigaridis, K., Vignati, E., Stephanou, E. G., and Wilson, J.: Organic aerosol and global climate modelling: a review, Atmos. Chem. Phys., 5, 1053-1123, doi:10.5194/acp-5-1053-2005, 2005.

Kinne, S., Schulz, M., Textor, C., Guibert, S., Balkanski, Y., Bauer, S. E., Berntsen, T., Berglen, T. F., Boucher, O., Chin, M., Collins, W., Dentener, F., Diehl, T., Easter, R., Feichter, J., Fillmore, D., Ghan, S., Ginoux, P., Gong, S., Grini, A., Hendricks, J., Herzog, M., Horowitz, L., Isaksen, I., Iversen, T., Kirkevåg, A., Kloster, S., Koch, D., Kristjansson, J. E., Krol, M., Lauer, A., Lamarque, J. F., Lesins, G., Liu, X., Lohmann, U., Montanaro, V., Myhre, G., Penner, J., Pitari, G., Reddy, S., Seland, O., Stier, P., Takemura, T., and Tie, X.: An AeroCom initial assessment - optical properties in aerosol component modules of global models, Atmos. Chem. Phys., 6, 1815-1834, doi:10.5194/acp-6-1815-2006, 2006.

Kirchstetter, T. W., Novakov, T., and Hobbs, P. V.: Evidence that the spectral dependence of light absorption by aerosols is affected by organic carbon, J. Geophys. Res.-Atmos., 109, D21208, doi:10.1029/2004JD004999, 2004.

Köpke, P., Hess, M., Schult, I., and Shettle, E.: Global aerosol data set, Tech. Rep. MPI Report No 243, Max-Planck-Institut für Meteorologie, Hamburg, Germany, 1997. 
Lamarque, J.-F., Bond, T. C., Eyring, V., Granier, C., Heil, A., Klimont, Z., Lee, D., Liousse, C., Mieville, A., Owen, B., Schultz, M. G., Shindell, D., Smith, S. J., Stehfest, E., Van Aardenne, J., Cooper, O. R., Kainuma, M., Mahowald, N., McConnell, J. R., Naik, V., Riahi, K., and van Vuuren, D. P.: Historical (1850-2000) gridded anthropogenic and biomass burning emissions of reactive gases and aerosols: methodology and application, Atmos. Chem. Phys., 10, 7017-7039, doi:10.5194/acp10-7017-2010, 2010.

Laurent, B., Marticorena, B., Bergametti, G., and Mei, F.: Modeling mineral dust emissions from Chinese and Mongolian deserts, Global Planet. Change, 52, 121-141, 2006.

Lee, L. A., Carslaw, K. S., Pringle, K. J., Mann, G. W., and Spracklen, D. V.: Emulation of a complex global aerosol model to quantify sensitivity to uncertain parameters, Atmos. Chem. Phys., 11, 12253-12273, doi:10.5194/acp-11-12253-2011, 2011.

Liu, D. C. and Nocedal, J.: On the limited memory BFGS method for large scale optimization, Math. Program., 45, 503-528, 1989.

Liu, Z., Liu, Q., Lin, H.-C., Schwartz, C. S., Lee, Y.-H., and Wang, T.: Three-dimensional variational assimilation of MODIS aerosol optical depth: Implementation and application to a dust storm over East Asia, J. Geophys. Res.-Atmos., 116, D23206, doi:10.1029/2011JD016159, 2011.

Louis, J.-F.: A parametric model of vertical eddy fluxes in the atmosphere, Bound.-Lay. Meteorol., 17, 187-202, 1979.

Lurton, T., Renard, J.-B., Vignelles, D., Jeannot, M., Akiki, R., Mineau, J.-L., and Tonnelier, T.: Light scattering at small angles by atmospheric irregular particles: modelling and laboratory measurements, Atmos. Meas. Tech., 7, 931-939, doi:10.5194/amt-7-931-2014, 2014.

Mahowald, N., Luo, C., del Corral, J., and Zender, C. S.: Interannual variability in atmospheric mineral aerosols from a 22-year model simulation and observational data, J. Geophys. Res.-Atmos., 108, 4352, doi:10.1029/2002JD002821, 2003.

Martet, M., Peuch, V.-H., Laurent, B., Marticorena, B., and Bergametti, G.: Evaluation of long-range transport and deposition of desert dust with the CTM MOCAGE, Tellus B, 61, 449-463, 2009.

Marticorena, B., Bergametti, G., Aumont, B., Callot, Y., N'doumé, C., and Legrand, M.: Modeling the atmospheric dust cycle: 2. Simulation of Saharan dust sources, J. Geophys. Res.-Atmos., 102, 4387-4404, doi:10.1029/96JD02964, 1997.

Massart, S., Piacentini, A., Cariolle, D., Amraoui, L. E., and Semane, N.: Assessment of the quality of the ozone measurements from the Odin/SMR instrument using data assimilation, Can. J. Phys., 85, 1209-1223, 2007.

Massart, S., Clerbaux, C., Cariolle, D., Piacentini, A., Turquety, S., and Hadji-Lazaro, J.: First steps towards the assimilation of IASI ozone data into the MOCAGE-PALM system, Atmos. Chem. Phys., 9, 5073-5091, doi:10.5194/acp-9-5073-2009, 2009.

Massart, S., Pajot, B., Piacentini, A., and Pannekoucke, O.: On the merits of using a 3D-FGAT assimilation scheme with an outer loop for atmospheric situations governed by transport, Mon. Weather Rev., 138, 4509-4522, 2010.

Massart, S., Piacentini, A., and Pannekoucke, O.: Importance of using ensemble estimated background error covariances for the quality of atmospheric ozone analyses, Q. J. Roy. Meteor. Soc., 138, 889-905, 2012.
Ménard, R., Cohn, S. E., Chang, L.-P., and Lyster, P. M.: Assimilation of stratospheric chemical tracer observations using a Kalman filter. Part I: Formulation, Mon. Weather Rev., 128, 2654-2671, 2000.

Nho-Kim, E.-Y., Michou, M., and Peuch, V.-H.: Parameterization of size-dependent particle dry deposition velocities for global modeling, Atmos. Environ., 38, 1933-1942, 2004.

Niu, T., Gong, S. L., Zhu, G. F., Liu, H. L., Hu, X. Q., Zhou, C. H., and Wang, Y. Q.: Data assimilation of dust aerosol observations for the CUACE/dust forecasting system, Atmos. Chem. Phys., 8, 3473-3482, doi:10.5194/acp-8-3473-2008, 2008.

Pagowski, M. and Grell, G. A.: Experiments with the assimilation of fine aerosols using an ensemble Kalman filter, J. Geophys. Res.-Atmos., 117, D21302, doi:10.1029/2012JD018333, 2012.

Pannekoucke, O. and Massart, S.: Estimation of the local diffusion tensor and normalization for heterogeneous correlation modelling using a diffusion equation, Q. J. Roy. Meteor. Soc., 134, 1425-1438, 2008.

Parrish, D. F. and Derber, J. C.: The National Meteorological Center's spectral statistical-interpolation analysis system, Mon. Weather Rev., 120, 1747-1763, 1992.

Piguet B. and Perrin T.: ATR Core in-situ measurements TRAQA, ChArMEx database, available at: http://mistrals.sedoo. fr/ChArMEx/ (registration required, last access: November 2016), doi:10.6096/MISTRALS-ChArMEx.998, 2013.

Rasch, P. J., Collins, W. D., and Eaton, B. E.: Understanding the Indian Ocean Experiment (INDOEX) aerosol distributions with an aerosol assimilation, J. Geophys. Res.-Atmos., 106, 7337-7355, doi:10.1029/2000JD900508, 2001.

Remer, L. A., Kaufman, Y., Tanré, D., Mattoo, S., Chu, D., Martins, J. V., Li, R.-R., Ichoku, C., Levy, R., Kleidman, R., Eck, T., Vermote, D., and Holben, B.: The MODIS aerosol algorithm, products, and validation, J. Atmos. Sci., 62, 947-973, doi:10.1175/JAS3385.1, 2005 .

Renard J.-B.: LOAC - TRAQA - Martigues, ChArMEx database, available at: http://mistrals.sedoo.fr/ChArMEx/ (registration required, last access: November 2016), doi:10.6096/MISTRALSChArMEx.833, 2012

Renard, J.-B., Dulac, F., Berthet, G., Lurton, T., Vignelles, D., Jégou, F., Tonnelier, T., Thaury, C., Jeannot, M., Couté, B., Akiki, R., Mineau, J.-L., Verdier, N., Mallet, M., Gensdarmes, F., Charpentier, P., Mesmin, S., Duverger, V., Dupont, J.-C., Elias, T., Crenn, V., Sciare, J., Giacomoni, J., Gobbi, M., Hamonou, E., Olafsson, H., Dagsson-Waldhauserova, P., Camy-Peyret, C., Mazel, C., Décamps, T., Piringer, M., Surcin, J., and Daugeron, D.: LOAC: a small aerosol optical counter/sizer for ground-based and balloon measurements of the size distribution and nature of atmospheric particles - Part 1: Principle of measurements and instrument evaluation, Atmos. Meas. Tech. Discuss., 8, 12031259, doi:10.5194/amtd-8-1203-2015, 2015.

Rubin, J. I., Reid, J. S., Hansen, J. A., Anderson, J. L., Collins, N., Hoar, T. J., Hogan, T., Lynch, P., McLay, J., Reynolds, C. A., Sessions, W. R., Westphal, D. L., and Zhang, J.: Development of the Ensemble Navy Aerosol Analysis Prediction System (ENAAPS) and its application of the Data Assimilation Research Testbed (DART) in support of aerosol forecasting, Atmos. Chem. Phys., 16, 3927-3951, doi:10.5194/acp-16-3927-2016, 2016.

Schutgens, N. A. J., Miyoshi, T., Takemura, T., and Nakajima, T.: Applying an ensemble Kalman filter to the assimilation of 
AERONET observations in a global aerosol transport model, Atmos. Chem. Phys., 10, 2561-2576, doi:10.5194/acp-10-25612010, 2010.

Seinfeld, J. H. and Pandis, S. N.: Atmospheric chemistry and physics: from air pollution to climate change, John Wiley \& Sons, New York, USA, 1998.

Sekiyama, T. T., Tanaka, T. Y., Shimizu, A., and Miyoshi, T.: Data assimilation of CALIPSO aerosol observations, Atmos. Chem. Phys., 10, 39-49, doi:10.5194/acp-10-39-2010, 2010.

Shindell, D. T., Lamarque, J.-F., Schulz, M., Flanner, M., Jiao, C., Chin, M., Young, P. J., Lee, Y. H., Rotstayn, L., Mahowald, N., Milly, G., Faluvegi, G., Balkanski, Y., Collins, W. J., Conley, A. J., Dalsoren, S., Easter, R., Ghan, S., Horowitz, L., Liu, X., Myhre, G., Nagashima, T., Naik, V., Rumbold, S. T., Skeie, R., Sudo, K., Szopa, S., Takemura, T., Voulgarakis, A., Yoon, J.-H., and Lo, F.: Radiative forcing in the ACCMIP historical and future climate simulations, Atmos. Chem. Phys., 13, 2939-2974, doi:10.5194/acp-13-2939-2013, 2013.

Sič, B., El Amraoui, L., Marécal, V., Josse, B., Arteta, J., Guth, J., Joly, M., and Hamer, P. D.: Modelling of primary aerosols in the chemical transport model MOCAGE: development and evaluation of aerosol physical parameterizations, Geosci. Model Dev., 8, 381-408, doi:10.5194/gmd-8-381-2015, 2015.

Slinn, W.: Some approximations for the wet and dry removal of particles and gases from the atmosphere, Water Air Soil Poll., 7, 513-543, 1977.

Strapp, J. W., Leaitch, W., and Liu, P.: Hydrated and dried aerosolsize-distribution measurements from the particle measuring systems FSSP-300 probe and the deiced PCASP-100X probe, J. Atmos. Ocean. Tech., 9, 548-555, 1992.

Talagrand, O.: A Posteriori Validation of Assimilation Algorithms, in: Data Assimilation for the Earth System, edited by: Swinbank, R., Shutyaev, V., and Lahoz, W., NATO Science Series, Springer Netherlands, 26, 85-95, doi:10.1007/978-94-010-00291_8, 2003.

Textor, C., Schulz, M., Guibert, S., Kinne, S., Balkanski, Y., Bauer, S., Berntsen, T., Berglen, T., Boucher, O., Chin, M., Dentener, F., Diehl, T., Easter, R., Feichter, H., Fillmore, D., Ghan, S., Ginoux, P., Gong, S., Grini, A., Hendricks, J., Horowitz, L., Huang, P., Isaksen, I., Iversen, I., Kloster, S., Koch, D., Kirkevåg, A., Kristjansson, J. E., Krol, M., Lauer, A., Lamarque, J. F., Liu, X., Montanaro, V., Myhre, G., Penner, J., Pitari, G., Reddy, S., Seland, Ø., Stier, P., Takemura, T., and Tie, X.: Analysis and quantification of the diversities of aerosol life cycles within AeroCom, Atmos. Chem. Phys., 6, 1777-1813, doi:10.5194/acp-6-1777-2006, 2006.
Thieuleux, F., Moulin, C., Bréon, F. M., Maignan, F., Poitou, J., and Tanré, D.: SEVIRI Level-2 Aerosol Products (AOT and AE) over Ocean (SEV_AER-OC-L2), ICARE data centre, University of Lille, available at: http://www.icare.univ-lille1.fr (registration required, last access: November 2016), 2005a.

Thieuleux, F., Moulin, C., Bréon, F. M., Maignan, F., Poitou, J., and Tanré, D.: Remote sensing of aerosols over the oceans using MSG/SEVIRI imagery, Ann. Geophys., 23, 3561-3568, doi:10.5194/angeo-23-3561-2005, 2005 b.

Tombette, M., Mallet, V., and Sportisse, B.: PM $_{10}$ data assimilation over Europe with the optimal interpolation method, Atmospheric Chemistry and Physics, 9, 57-70, doi:10.5194/acp-9-572009, 2009.

Tréemolet, Y.: Accounting for an imperfect model in 4D-Var, Q. J. Roy. Meteor. Soc., 132, 2483-2504, doi:10.1256/qj.05.224, 2006.

Vignati, E., Karl, M., Krol, M., Wilson, J., Stier, P., and Cavalli, F.: Sources of uncertainties in modelling black carbon at the global scale, Atmos. Chem. Phys., 10, 2595-2611, doi:10.5194/acp-102595-2010, 2010.

Weaver, A. and Courtier, P.: Correlation modelling on the sphere using a generalized diffusion equation, Q. J. Roy. Meteor. Soc., 127, 1815-1846, 2001.

Williamson, D. L. and Rasch, P. J.: Two-dimensional semiLagrangian transport with shape-preserving interpolation, Mon. Weather Rev., 117, 102-129, 1989.

Wiscombe, W. J.: Mie scattering calculations: advances in technique and fast, vector-speed computer codes, Atmospheric Analysis and Prediction Division, National Center for Atmospheric Research, 1979.

Wiscombe, W. J.: Improved Mie scattering algorithms, Appl. Opt., 19, 1505-1509, 1980.

Yumimoto, K., Uno, I., Sugimoto, N., Shimizu, A., Liu, Z., and Winker, D. M.: Adjoint inversion modeling of Asian dust emission using lidar observations, Atmos. Chem. Phys., 8, 28692884, doi:10.5194/acp-8-2869-2008, 2008.

Zhang, J., Reid, J. S., Westphal, D. L., Baker, N. L., and Hyer, E. J.: A system for operational aerosol optical depth data assimilation over global oceans, J. Geophys. Res.-Atmos., 113, D10208, doi:10.1029/2007JD009065, 2008. 